\title{
ИСТОКИ РУССКОЙ ПОЛИТОЛОГИИ: О ПОЛИТИЧЕСКИХ НАУКАХ В ПОХВАЛЬНОМ СЛОВЕ ИОАННА (ИОГАННА) ГОТФРИДА РЕЙХЕЛЯ, АДРЕСОВАННОМ ЕКАТЕРИНЕ II ВЕЛИКОЙ
}

\begin{abstract}
Аннотация
Статья посвящена первому официальному библиотекарю Московского университета Иоанну (Иоганну) Готфриду Рейхелю и его похвальному слову, адресованному Екатерине II Великой. Автор делает предположение, что именно с текста И.Г. Рейхеля «О наилучших способах к умножению подданных» (1766) начинается история русской политологии политической науки в России. Рейхель опубликовал свою работу на русском языке, использует понятие «политические науки», ссылается на авторов, которые стояли у истоков таких научных направлений, как «политическая арифметика», «политическая экономия", «статистика», «демография». Рейхель оказал большое влияние на образование целого поколения просвещенных людей России, в том числе и на братьев Фонвизиных. Денис Фонвизин в одном из художественных произведений в 1788 году выступил за создание кафедр политической науки в российских университетах. Также при содействии представителей Русской православной церкви Рейхель издал первый в России учебник по статистике, а по сути - первое пособие по политической компаративистике.

Статья о Рейхеле предваряет публикацию похвального слова «О наилучших способах к умножению подданных», адресованного Екатерине II Великой, в журнале «Русская политология - Russian Political Science» с комментариями, пояснениями и с учетом современных правил грамматики. Переиздание работы Рейхеля осуществляется впервые за 255-летнюю историю этого текста.
\end{abstract}

Ключевые слова: политические науки, политическая наука, политология, русская политология, Иоанн (Иоганн) Готфрид Рейхель, история политической науки, Екатерина II.

DOI: 10.51180/RPS.2021.18.1.006

\section{Автор}

\section{Горохов Андрей Анатольевич}

Кандидат политических наук, главный редактор журнала «Русская политология - Russian Political Science» (Москва, Россия)

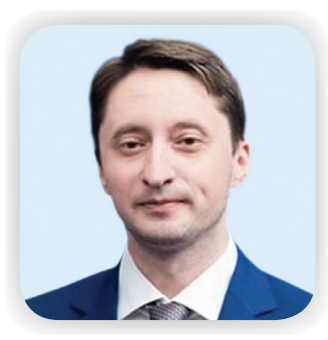

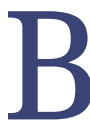
журнале «Русская политология Russian Political Science» мы уже обращались к вопросу истоков политической науки в России, например, в 2018 году, в выпуске № 1 (6), была опубликована статья «Некоторые замечания об обсуждении истоков политологии в России» [3], которую написали политологи Эдуард Елиньски и Бартош Хордецки. В этой работе был достаточно подробно рассмотрен вопрос о зарождении политологии в России. Безусловно, правы современные авторы $[17 ; 23 ; 25]$, которые находят истоки политической науки в Российской империи, в XVIII и XIX веках, так как этот факт подтверждается документально - имеются опубликованные издания, исследования. Назовем для примера несколько таких работ. В 1771 году в день рождения Екатерины II ординарный профессор кафедры всеобщей юриспруденции юридического факультета Императорского Москов- 
64 РУССКАЯ ПОЛИТОЛОГИЯ — RUSSIAN POLITICAL SCIENCE. 2021. № 1 (18) Истоки русской политологии и политической мысли

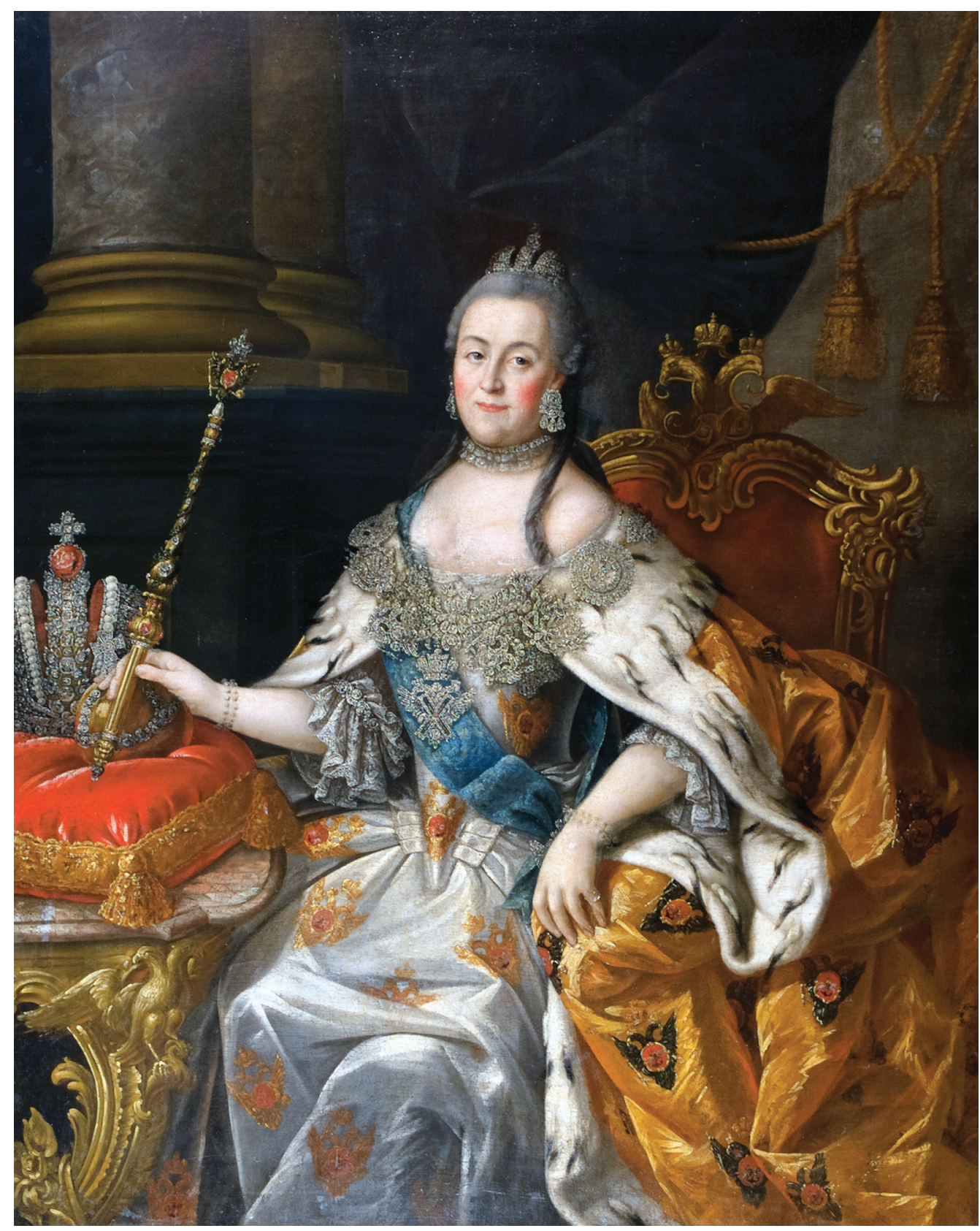

Портрет Екатерины II (1729-1796). 1760-е гг. Холст, масло. 154,5×122,5 см. КОКГ КП-1/557. ж-10. Автор: Антропов Алексей Петрович (1716-1795)

() Тверская областная картинная галерея. 
ского университета Карл Генрих Лангер (вторая половина 1730-х годов - после 1792 года) прочитал торжественную речь, которая была опубликована на латыни под заголовком «De ambietu et praecipuis doctrinae politicae scriptoribus. Oratio sollemnis, quam occasione festi natalis Augustissimae ac Potentissimae totius Rossiae Imperatricis et Autocratoris Catharinae II Magnae...» [28]. Речь Лангера в наши дни была переведена и издана на русском языке под названием «О пределах и важнейших представителях политической науки» [5]. Именно данный текст в настоящее время рассматривается как первая публикация по политической науке в Московском университете [30]. На другом похвальном слове, адресованном Екатерине II и имеющем отношение к истокам зарождения русской политологии, мы остановимся чуть ниже, а сейчас назовем еще несколько работ о политических науках, которые были изданы в Российской империи в XIX веке.

В 1833 году профессор политической экономии и дипломатии Харьковского университета Тихон Федорович
Степанов (1795-1847) произнес речь «О сущности, важности и назначении политических наук» [21]. Т.Ф. Степанов в этой работе на вопрос о том, что является сутью политических наук, ответил следующим образом: «Политические науки излагают нам те законы, по которым государства живут и раскрываются в своей жизни постепенным совершенствованием» [21. - С. 4]. Будущий академик Петербургской академии наук (1851) и декан историко-филологического факультета Петербургского университета (18551880) Измаил Иванович Срезневский (1812-1880) в 1837 году представил и издал магистерскую диссертацию «Опыт о сущности и содержании теории в науках политических» [20]. В начале своей работы И.И. Срезневский определяет предмет политических наук как «государство и вообще государственная жизнь рода человеческого» [20. - C. VII]. В 1872 году социологом и писателем Александром Ивановичем Строниным (1827-1889) была издана книга «Политика как наука» [22]. Можно и далее перечислять подобные работы,

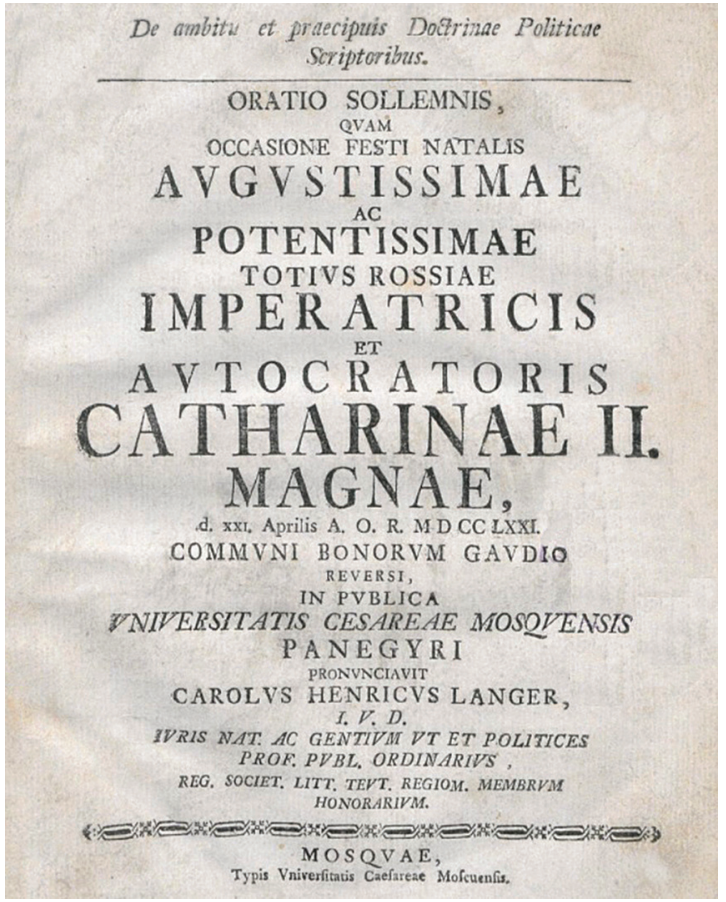

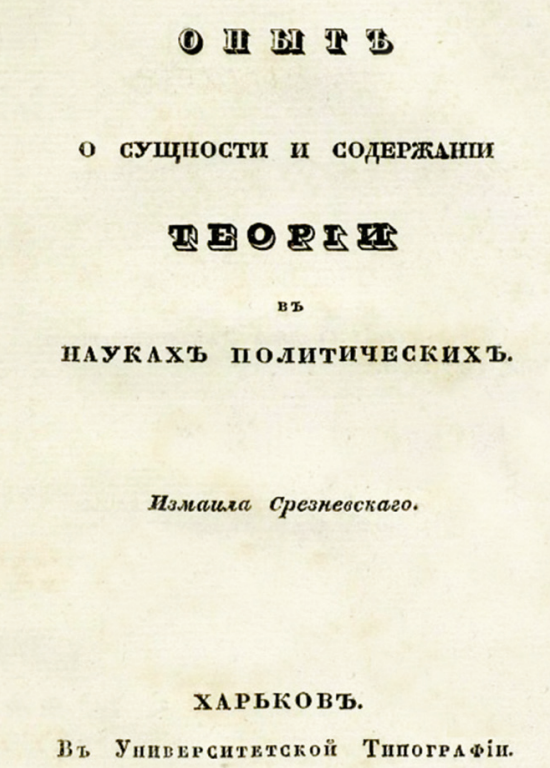

ง857. 


\section{ПОЛИТИКА}

\author{
ILAFCF IEAJECA.
}

A. СТтрониния.

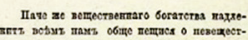

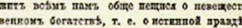
Ilocomroms (O crypocri II Goranerat)

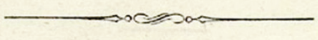

С.-ПЕТЕРБУРГЪ.

В т типогРАФІІ Ф. С. СущйевАто. Еватернинискій ваваль, 168.

1872.

которые были изданы в Российской империи, но очевидно, что отрицать факт зарождения политической науки в России в XVIII-XIX веках - это игнорировать очевидные факты: не замечать письменное историческое наследие, которое сохранилось и находится в современных библиотеках. Библиотеки, помимо этого, были одним из центров развития политической науки в России.

В частности, в Российской государственной библиотеке (РГБ) хранится работа под заглавием «О наилучших способах к умножению подданных" [8] - это похвальное слово, адресованное Екатерине II, которое было прочитано 30 июня (11 июля) 1766 года в Императорском Московском университете Иоанном (Иоганном) Готфридом Рейхелем (1727-1778). И.Г. Рейхель до приезда в Россию учился в Лейпцигском университете, в Московском университете был экстраординарным профессором (1761), ординарным профессором кафедры истории (универсальной, российской, древности и геральдики) (1764-1778) философского факультета. И что примечательно, он был первым

\section{$\mathcal{P} \mathscr{S} \mathscr{X}$,}

О СУЩНОСТИ, ВАЖНОСТИ И НАЗНАЧЕНІИ ПОАИТИЧЕСКИХЬ

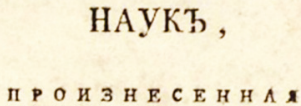

$\mathrm{B} \mathrm{b}$

Торжествснномз Собранй и

НМПЕРАТОРСКАГО Харьковскаго Университета Э. О. Продессоромб Политигеской Экономіи и Ӓипоматіи

Тихономз Cтепановвкв.

50 Августга 1853 года.

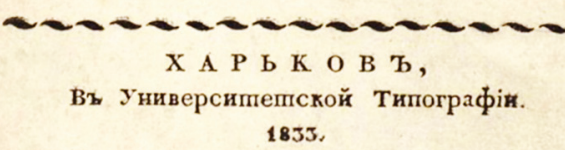

официальным библиотекарем Московского университета (1761-1778) [7] - это сказалось на работах, которые Рейхель опубликовал в России. В его текстах имеются множественные отсылки к разным авторам, в частности, к основателям и видным представителям демографии, политической арифметики, политической экономии, статистики (Джон Граунт, Уильям Петти, Грегори Кинг, Иоганн Петер Зюсмильх и др.).

Сам Рейхель в 1764-1765 годах читал курс статистического содержания, а в 1772-1773 академическом году он первый читал статистику. Именно с его курса начинается история преподавания статистики в Московском университете. Здесь необходимо пояснить, что статистика в XVIII веке понималась как государствоведение. Лекции Рейхеля по статистике были изданы на русском в 1775 году под заглавием «Краткое руководство к познанию натурального, церковного, политического, экономического и учебного состояния некоторых знатнейших европейских государств» [11]. В этой книге, по сути, в первом учебнике по статистике в России, описано 
восемь государств: Испания, Португалия, Франция, Великобритания, Соединенные Нидерланды, Дания, Швеция и Польша. Данную книгу можно рассматривать также как предтечу одного из направлений политической науки компаративистики и первый учебник по политическим наукам в России.

Необходимо добавить, что эта книга была составлена из лекций Рейхеля и переведена на русский язык его слушателем, выпускником московской Славяно-греко-латинской академии и философского факультета Московского университета Андреем Дмитриевичем Байбаковым (1737-1801), иеромонахом Аполлосом (пострижен в монашество в 1774 году). Впоследствии Аполлос (Байбаков) стал наместником ТроицеСергиевой лавры (1782-1783), архимандритом Заиконоспасского монастыря и ректором Московской духовной академии (1783-1786), настоятелем Воскресенского Ново-Иерусалимского монастыря (1786-1788), епископом Орловским и Севским (с 1788), Архангельским и Холмогорским (с 1798), членом Российской академии (с 1786). Аполлос (Байбаков) принимал участие в создании «Словаря Академии Российской» (первый толковый словарь русского языка), он автор многих работ, в том числе следующих: «Грамматика, руководствующая к познанию Славенороссийского языка», «Правила пиитического российского и латинского стихосложения, собранные из разных лет».

Нам представляется, что сотрудничество Рейхеля и Аполлоса (Байбакова) было основано на общих научных и религиозных интересах, так как Рейхель, помимо статистики и истории, интересовался православием, проблематикой религиоведения - выступил с критикой ${ }^{1}$ диссертации «Рассуждение

${ }^{1}$ В Московском главном архиве Министерства иностранных дел в 1855 г. хранилась речь Рейхеля, в которой он возражал против неправильных, с точки зрения религии, мнений, изложенных Д.С. Аничковым (см.: Русский биографический словарь: Рейтерн - Рольцберг / из натуральной богословии о начале и происшествии натурального богопочитания» (1769) [1], которая была подготовлена Дмитрием Сергеевичем Аничковым (1733-1788) на соискание профессорского звания в Московском университете. В том числе и усилиями Рейхеля диссертация была признана противоречащей догматам православия, а соискателю пришлось переписывать свою работу. При этом необходимо заметить, что именно Д.С. Аничков был автором первого философского курса на русском языке в Московском университете. Также Рейхель перевел на немецкий язык «Догматы христианской православной веры» [2] епископа Феофилакта (Горского) и издал ее в типографии Университета в 1773 г. под заглавием: «Grundlehren der christlichen Orthodoxen Religion, welche in seinen theologischen Vorlesungen vorgetragen und erkläret Se. Hochwürden der Archimandrit Theophylakt, Rector der Moskowischen Akademie und Lehrer der Theologie...» [26].

Сочетание православной традиции и научных знаний - это основа исследовательской и преподавательской деятельности Рейхеля, а также идейная платформа становления политической науки в России. Поэтому пауза в развитии политической науки в стране, вызванная революцией 1917 года и крахом империи, имеет не только политическое объяснение, но и идейнодуховное.

Более подробная биография Рейхеля изложена в «Русском биографическом словаре» [16].

Иоанн (Иоганн) Готфрид Рейхель, кроме уже названных работ, является автором еще целой серии публикаций, в частности: «Краткая история о Японском государстве, из достоверных известий собранная» (1773) [10], «История о знатнейших европейских государствах

Изд. Императорского Русского исторического общества. - СПб.: Тип. Императорской Акад. наук, 1913 [2]. - T. 16). 
с кратким введением в древнюю историю, продолжающуюся до нынешних времен» (пер. с лат. опубликован в 1788 г.) [9].

Помимо перечисленных текстов сохранились публичные лекции и выступления И.Г. Рейхеля - это «Слово о том, что науки и художества процветают защищением и покровительством владеющих особ и великих людей в государстве» (1762; перевод Д.И. Фонвизина) [13], «Слово о художествах древних» (1770) [12], «Цветущее состояние и слава России, от геройских добродетелей ее Самодержицы происходящие» (1772) [14], «История просвещения в Императорском Московском университете» (1773-1774, на лат.) [27], «Слово о способе, каким древние возбуждали в гражданах любовь к Отечеству» (1775) [15].

Из письменного наследия Рейхеля мы обратили внимание на текст «О наилучших способах к умножению подданных", так как рассматриваем данную работу как один из первых письменных памятников русской политической науки. Почему мы так считаем? Во-первых, в своей речи - в похвальном слове Рейхель использует понятие «политические науки». Обращаясь к историческому наследию, к работам мыслителей как прошлого, так и XVIII века, Рейхель писал: «...опыт научил, что такие труды не только принесли много просвещения к истолкованию сей материи, но и другим, в политических науках упражняющимся, дорогу показали, по которой они в пользу государства изобрели весьма важные и полезные истины/» [8. - С. 6]. Тем самым автор обозначает политические науки как то, что открывает истины, знания, полезные для развития государства. А заглавием и содержанием данной работы он отвечает на вопрос о том, что является полезным для государства, это умножение подданных, увеличение населения в стране.

Во-вторых, работа Рейхеля имеет отношение к политическим наукам, так как он в своей речи отсылает слуша- телей (в настоящее время читателей) к мыслителям, которые стали основателями тех направлений и дисциплин, с которых и начинается современная политическая наука, а именно: направление эмпирических исследований «политическая арифметика», статистика, политическая экономия.

В-третьих, Рейхель, опираясь на научный опыт его времени, перечисляет пять важных социально-экономических и политических направлений, которые государство должно развивать, чтобы увеличивалось количество подданных: - совершенствовать сельское хозяйство (земледелие);

- оберегать внутренний и внешний мир, который ведет к благополучию и благосостоянию (мир);

- заботиться о здоровье подданных (здравоохранение);

- способствовать созданию брачных союзов (супружество);

- привлекать в страну иностранцев «чрез доброе правление, плодородие земли и легкость получать вещи, к жизни потребные, дабы они в таковых границах жилище иметь восхотели» 8] (зарубежные подданные). При этом Рейхель пишет о необходимости уделять пристальное внимание воспитанию молодого поколения и отмечает негативное влияние роскоши на демографические процессы. В то же время пишет, что роскошь многие понимают по-разному - для одних и занятия свободными науками воспринимаются как роскошь. Таким образом, тезис о роскоши Рейхель не раскрывает в своей работе.

Рейхель, имея высокий уровень теоретических знаний в области политических наук его исторического периода, составил на основе научных знаний, по сути, социально-экономические рекомендации по управлению Российской империей, показывая прикладной характер политической науки. В результате, как нам представляется, Рейхель на заре зарождения политической науки в России - русской 
политологии - заложил одну из ее основ - это ориентир на решение государственных задач через использование всего комплекса накопившихся научных знаний. Поэтому в его работе мы видим широкий спектр перечисленных исследователей, которые изучали проблематику, связанную с динамикой и увеличением численности подданных.

И в-четвертых, текст Рейхеля был издан на русском языке, хотя изначально работа была произнесена и напечатана на латыни под заголовком «De optimis civium frequentiam augendi modis» [29], но в этом же году была переведена и издана на русском. Переводчик в издании не указывается, что может говорить о том, что Рейхель сам перевел текст. Вопрос языка произведения очень важен, так как до момента формирования понятийного аппарата политической науки на русском языке невозможно вести речь о зарождении самостоятельной политической науки в России, а тем более о русской политологии и о традициях политической науки в нашей стране. Здесь необходимо отметить, что под руководством Рейхеля студенты Университета переводили и издавали на русском языке статьи зарубежных авторов. В 1762 году Рейхель раз в три месяца издавал «Собрание лучших сочинений к распространению знания и к произведению удовольствия, или Смешанную библиотеку о разных физических, экономических, також до мануфактур и до коммерции принадлежащих вещах» [18; 19]. Издание состояло из переводов французских, английских, немецких выдержек из журнальных статей и книг. Среди переводчиков были в том числе Денис Иванович (1745-1792) и Павел Иванович Фонвизины (1746-1803). Д.И. Фонвизин - создатель русской бытовой комедии, секретарь (1769-1782) при руководителе Коллегии иностранных дел графе Никите Ивановиче Панине (1718-1783). П.И. Фонвизин - директор Московского университета (1784-
1796), член Сената (1796-1801). Известно, что именно под руководством Рейхеля Д.И. Фонвизин переводил с немецкого на русский басни норвежскодатского писателя Людвига Хольберга (1684-1754). В 1761 году Фонвизиным был составлен сборник из 183 басен [6]. Примечательно то, что Д.И. Фонвизин в своих произведениях обращался и к теме развития политической науки в России. Например, в периодическом сочинении, посвященном истине, «Друг честных людей, или Стародум» ${ }^{1}$ (1788) в беседе двух персонажей (Здравомысл и Сорванцов) Фонвизин, ученик Рейхеля, рассуждал о политической науке, более того, предлагал открыть кафедры политической науки в российских университетах ${ }^{2}$. Вот что писал Д.И. Фонвизин: «Здравомысл. Мы видим, что у нас об этом и помышляют. Когда в российских городах заводят университеты, то, стало, намерение есть готовить к службе людей просвещенных. Я хотел бы только, чтобы в университетах наших преподавалась особенно политическая наука.

Сорванцов. Что вы чрез сию науку разумеете?

Здравомысл. Разумею науку, научающую нас правилам благочиния, науку коммерческую и науку о государственных доходах. Я хотел бы, чтоб у нас по сим предметам сочинены были на каждую часть особенные книжки,

1 В 1788 году Фонвизин пытался получить разрешение издавать журнал "Друг честных людей, или Стародум». Ему было отказано, но материалы первого номера получили распространение в рукописном виде (см.: История русской журналистики XVIII-XIX веков / Под ред. проф. А.В. Западова. - 3-е, испр. изд. - М.: Высш. шк., 1973).

2 Алексей Дмитриевич Галахов (1807-1892) в работе «История русской словесности, древней и новой» утверждал, что в художественном произведении Фонвизин, размышляя о средствах приготовить достойных судей и адвокатов, предложил учредить в Университете кафедру политической науки (см.: Галахов А.Д. История русской словесности, древней и новой / Соч. А. Галахова. Т. 1-2. - СПб.: Тип. Гл. упр. воен.-учеб. завед., 1863-1875. - С. 424). 
по коим бы преподавалась в университетах политическая наука. Сим способом будет Россия иметь во всех частях гражданской службы людей годных и просвещенных. Я о сем размышлял довольно, но боюсь здесь распространиться, дабы не наскучить сим вам и тем, кои разговор наш читать будут.

Сорванцов. Я хотя и могу показаться вам головорезом, однако верьте мне, что я хотел бы сию минуту пойти учеником в тот университет, где мог бы сделаться годным к службе, и, оттуда вышед, знал бы я, что получу место не mо, где есть только вакансия, но то, для которого я учился и к которому способен.

Здравомысл. Если бы я знал, что моя идея о заведении в университетах класса политической науки найдена была полезною и угодною, я охотно составил бы мое мнение, как к сему приступить удобнее. Находясь в чужих краях, я видал сам таковой класс; имею книжки, по коим политическая наука преподается, и говорил с теми людьми, кои преподают сию науку, но, признаюсь вам, что без особенного побуждения боюсь вместо удовольствия нажить каких-нибудь неприятностей om тех людей, кои, сами пресмыкаясь в невежестве, думают, что для дел ничему учиться не надобно» [24. - С. 69].

Вернемся к первому библиотекарю Московского университета Рейхелю. Тема выступления Рейхеля и перечисленные условия для умножения населения в стране не только актуальны для XVIII века, но и чрезвычайно важны сегодня, в условиях пандемии COVID-19. Ее последствия ставят демографический вопрос на первый план на всех уровнях современного российского государства.

Еще раз хотим акцентировать внимание на том факте, что Рейхель в своей работе обращается к ученым, которые заложили такое направление, как «политическая арифметика», - это Джон Граунт (1620-1674), автор первых количественных описаний социально-демо- графических процессов; Уильям Петти (1623-1687) - экономист, основатель социально-экономической статистики, который дал название направлению «политическая арифметика»; Грегори Кинг (1648-1712) - английский статистик, продолживший работу Дж. Граунта иУ. Петти. Этот ориентир политической науки на анализ данных, особенно на заре ее зарождения, имеет большое значение и для современной науки, но уже на другом уровне - сегодня политологии необходимо найти адекватные методы для анализа и практического использования больших данных, так как общество в цифровую эпоху генерирует и накапливает огромные массивы информации. И главный вопрос современной политической науки - как полученные данные использовать для пользы развития общества и государства.

Помимо достижений науки нового времени, Рейхель придавал большое значение историческому опыту и наследию, в том числе и для решения демографических задач, именно поэтому в его работе мы видим ссылки на «закон Юлия и Папия-Поппея» (Lex Julia et Papia Poppaеа - семейное законодательство римского императора Августа (30 г. до н.э. - 14 г. н.э.)). Этим законодательством государство политико-правовыми методами впервые в истории стимулировало рождаемость и укрепляло семейные ценности.

То, что работа Рейхеля, отпечатанная типографией Московского университета в 1766 году, сохранилась до наших дней, - это большое везение, так как во время Отечественной войны 1812 года в Москве сгорела практически вся библиотека Университета, сохранилась лишь ее малая часть редчайшие экземпляры 51 книги и 12 рукописей, которые были вывезены в Нижний Новгород [4]. Вероятно, экземпляр работы «О наилучших способах к умножению подданных», хранившейся в библиотеке Московского университета, именно по этой причине был утрачен (в каталоге не найдена). 
Библиотека восстанавливалась из частных собраний и коллекций.

Неизвестно, читала ли текст выступления Рейхеля Екатерина II, но успехи ее правления общепризнаны: создана система среднего образования, заложены основы для развития женского образования, проведена первая вакцинация от оспы, темпы развития сельского хозяйства позволили России экспортироватьхлеб и т.д. Безусловно, политика Екатерины способствовала росту населения в стране. Уже на заре правления Екатерины II Рейхель, как нам представляется, хотел через похвальное слово показать, что многое предписанное учеными для увеличения числа подданных сделано Екатериной в России. Тем самым Рейхель подтверждал просвещенный статус императрицы Екатерины II - она правила на основе научных знаний, достижений политических наук.

Ниже мы публикуем в полном объеме текст выступления Рейхеля. Текст мы откорректировали и отредактировали, используя современные правила грамматики. Большую благодарность за помощь в работе над текстом Рейхеля выражаем Жанне Каратаевой и кандидату филологических наук Марии Хлупиной. К оригинальному тексту добавлены комментарии к именам, научным трудам и историческим событиям, для того чтобы современные читатели понимали, о ком, о каких научных работах и о каких событиях писал Иоанн (Иоганн) Готфрид Рейхель в 1766 году.

Также с текстом мы публикуем портрет Екатерины II, написанный в год издания работы Рейхеля (1766) живописцем Алексеем Петровичем Антроповым (1716-1795). Цифровая копия портрета любезно предоставлена Тверской областной картинной галереей, где и хранится это произведение художественного искусства. За возможность опубликовать копию картины Екатерины II выражаем отдельную благодарность директору Тверской областной картинной галереи Татьяне Савватеевне Куюкиной и научному сотруднику галереи Екатерине Балашовой.

С публикации похвального слова «О наилучших способах к умножению подданных», адресованного Екатерине II Великой, мы открываем в журнале «Русская политология - Russian Political Science» рубрику «Истоки русской политологии», в которой будем публиковать забытые тексты основателей политической науки в России и представителей русской социально-политической мысли. Осознав истоки, можно понять особенности и задачи современной политической науки в России - задачи, решение которых полезно и для государства, и для общества.

\section{Литература}

1. Аничков Д.С. Рассуждение из натуральной богословии о начале и происшествии натурального богопочитания. - М.: Печ. при Имп. Моск. ун-те. - 1769. - 23 с.

2. Догматы христианской православной веры [Текст] / в богословском учении предложенные и изъясненные Московской академии ректором, священного богословия учителем, архимандритом Феофилактом, а на немецкий язык переведенные Иоганном Готфридом Рейхелем, Императорского Московского университета профессором публичным ординарным, оного ж библиотекарем и конференц-секретарем и Лейпцигского общества свободных наук членом; Иждивением университетского книгопродавца Христиана Людвига Вевера. — М.: Печ. при Имп. Моск. ун-те, 1773. — 52 с.

3. Елиньски Э., Хордецки Б. Некоторые замечания об обсуждении истоков политологии в России // Русская политология —-Russian Political Science. — 2018. —№ 1 (6). - C. 143-151.

4. Климачева И. «Имеет быть отворена»: 260 лет Научной библиотеке MГУ. — URL: https:// tass.ru/kultura/3451943.

5. Лангер К.Г. О пределах и важнейших представителях политической науки [Текст] = De ambitu et praecipuis doctrinae politicae scriptoribus: Торжественное слово по случаю празднования рождения августейшей и могущественной всероссийской императрицы 
и самодержицы Екатерины II Великой, 1771 г. апреля 22 дня / Карл Генрих Лангер; [Московский гос. ун-т им. М.В. Ломоносова, фак-т политологии]. - М.: Изд-во Московского ун-та, 2011. - 127 с.

6. Макогоненко Г.П. История изданий сочинений Д.И. Фонвизина и судьба его литературного наследства // Фонвизин Д.И. Собрание сочинений. - Т. 2. - М.; Л., 1959. С. 622-664.

7. Рейхель Иоганн Готфрид. — URL: http://letopis.msu.ru/peoples/567.

8. Рейхель И.Г. О наилучших способах к умножению подданных: Похвальное слово всепресветлейшей, державнейшей, великой государыне императрице и самодержице всероссийской, августейшей нашей монархине Екатерине Второй, Императорского Московского университета в публичном собрании июня 30 дня 1766 года бывшем для всерадостного дня восшествия Ее Императорского Величества на всероссийский императорский престол, говоренное истории профессором публичным, университетским библиотекарем и Лейпцигского собрания свободных наук членом Иоганном Готфридом Рейхелем. - М.: Печ. при Имп. Моск. ун-те, 1766. - 20 с.

9. Рейхель И.Г. История о знатнейших европейских государствах с кратким введением в древнюю историю, продолжающаяся до нынешних времен / Перевел с латинского языка губернский секретарь и вышнего исторического и географического класса при гимназиях Имп. Московского университета информатор Михаил Падерин. - М.: Унив. тип., у Н. Новикова, 1788. - 514 с.

10. Рейхель И.Г. Краткая история о Японском государстве, из достоверных известий собранная. - М.: Унив. тип., 1773. - 239 с.

11. Рейхель И.Г. Краткое руководство к познанию натурального, церковного, политического, экономического и учебного состояния некоторых знатнейших европейских государств собранное, из публичного в 1773 году обучения истории в Имп. Московском университете и до самых новейших времен продолженное / Переведено с латинского. - М.: Печ. при Имп. Моск. ун-те, 1775. - 316 с.

12. Рейхель И.Г. Слово о художествах древних, в которых замысл и искусство художников похвалу заслуживают, посвященное дню рождения Екатерины II и в публичном Императорского Московского университета собрании на другой день онаго, апреля 22 дня 1770 года говоренное Иоанном Готфридом Рейхелем, истории профессором публичным ординарным, университетским библиотекарем и Лейпцигского общества свободных наук членом. - М.: Печ. при Имп. Моск. ун-те, 1770. - 31 с.

13. Рейхель И.Г. Слово, говоренное по совершении высочайшего коронования Ее Всепресветлейшего Величества, благочестивейшей великой государыни Екатерины Второй, императрицы и самодержицы всероссийской, в публичном собрании Императорского Московского университета октября 3 дня 1762 года истории профессором, университетским библиотекарем и Лейпцигского собрания свободных наук членом Иоганном Готфридом Рейхелем, о том, что науки и художества процветают защищением и покровительством владеющих особ и великих людей в государстве / Перевел Денис Фонвизин. - М.: Печ. при Имп. Моск. ун-те, 1762. - 14 с.

14. Рейхель И.Г. Цветущее состояние и славу России, от геройских добродетелей ее самодержицы происходящую: В десятилетнее торжество благополучного правления августейшей монархини великой государыни Екатерины II, императрицы и самодержицы всероссийской и проч. и проч. и проч., в публичном Императорского Московского университета собрании июня 30 дня 1772 года празднованное, с глубочайшим усердием изъявляет избранный к тому оратор Иоанн Готфрид Рейхель, истории профессор публ. ордин., библиотекарь, университ. конференц-секретарь и Лейпцигск. учен. общества член; Перевел с лат. истор. учит. Харитон Чеботарев. - М.: Печ. при Имп. Моск. ун-те, 1772. $-24 \mathrm{c}$.

15. Рейхель И.Г. Слово о способе, каким древние возбуждали в гражданах любовь к отечеству: На высокоторжественный день рождения августейшей монархини великой государыни Екатерины II, императрицы и самодержицы всероссийской и проч. и проч. и проч., с глубочайшим благоговением празднованный апреля 22 дня 1775 года в Императорском Московском университете, говоренное Иоганном Готфридом Рейхелем, истории профессором публичным ординарным; Перевел слатинского унив. суббиблиот. Харитон Чеботарев. - М.: Печ. в Унив. тип., 1775. - 23, [1] с. 
16. Русский биографический словарь: Рейтерн - Рольцберг / Изд. Императорского Русского исторического общества. - СПб.: Тип. Императорской акад. наук, 1913 [2]. — Т. 16.

17. Сморгунов Л.В. Очерки истории политических наук в Санкт-Петербургском университете XIX в. // Российская политическая наука: Истоки, традиции и перспективы: Мат-лы Всероссийской научной конференции (с международным участием). Москва, 21-22 ноября 2014 г. - М., 2014.

18. Собрание лучших сочинений к распространению знания и к произведению удовольствия, или Смешанная библиотека о разных физических, экономических, також до манифактур и до коммерции принадлежащих вещах. - М.: У Вевера и Сколария, 1762. - Ч. 1: на месяцы январь, февраль и март. - 1762. - 180 с.

19. Собрание лучших сочинений к распространению знания и к произведению удовольствия, или Смешанная библиотека о разных физических, экономических, також до манифактур и до коммерции принадлежащих вещах. - М.: У Вевера и Сколария, 1762. - Ч. 2: на месяцы апрель, май и июнь. - 1762. - С. 181-336.

20. Срезневский И. Опыт о сущности и содержании теории в науках политических: [Рассуждение, писанное на получение степ. магистра полит. истории и статистики]. - Харьков: Унив. тип., 1837. -77 с.

21. Степанов Т.Ф. Речь о сущности, важности и назначении политических наук, произнесенная в торжественном собрании Харьковского университета э.о. профессором политической экономии и дипломатии Тихоном Степановым 30 авг. 1833 г. -Харьков: Унив. тип., 1833. - 64 с.

22. Стронин А. Политика как наука. - СПб.: Тип. Ф.С. Сущинскаго, 1872. - 530 с.

23. Топычканов А.В. Политические науки в России в эпоху Университетского устава 1863 г.: проблемы институализации // Central European Political Studies. - 2014. - № 4. С. $141-158$.

24. Фонвизин Д.И. Друг честных людей, или Стародум // Фонвизин Д.И. Собрание сочинений в двух томах. - М.; Л.: Гос. изд-во художественной литературы, 1959. - Т. 2. - С. 40-78.

25. Шутов А.Ю. Предмет политической науки: взгляд из XVIII века. Карл Генрих Лангер. О пределах и важнейших представителях политической науки // Избранные труды профессоров нравственно-политического отделения МГУ. - М., 2011.

26. Grundlehren der christlichen Orthodoxen Religion welche in seinen theologischen Vorlesungen vorgetragen und erkläret seine Hochwürden der Archimandrit Theophilakt Rector der Moskovischen Akademie und Lehrer der Theologie und in das Deutsche übersetzet Johann Gottfried Reichel bey der Kaiserlichen Universität zu Moskau öffentlicher und ordentlicher Professor der Geschichte, Bibliothekar, Konferenz-Sekretär und Mitglied der Gesellschaft der Freyen Künste zu Leipzig. - Moskau: Gedruckt bey der Kaiserlichen Universität, auf Kosten des Universitats-Buchhändlers Christian Ludwig Wever, 1773. — 32 p.

27. Historia Eruditionis, in Universitate Caesarea Moscuensi a domino Johanne Godofredo Reichel, professore P.O., bibliothecario primario, conventus Academici secretario, in [publicis] (?) lectionibus $13 \mathrm{~d}$. aug[...] 1773 - 23 d. junij 1774 e[хро]sita: [рукопись второй половины 18 в. (1770-е) на латинском языке]. - 497 р.

28. Langer K.H. De ambietu et praecipuis doctrinae politicae scriptoribus: Oratio sollemnis, quam occasione festi natalis augustissimae ac potentissimae totius Rossiae imperatricis et autocratoris Catharinae II Magnae, d. 21 Aprilis A.O.R. 1771, communi bonorum quadio reversi, in publica Universitatis Caesareae Mosquensis panegyri pronunciavit Carolus Heinricus Langer, I.V.D. juris nat. ac gentium ut et politices prof. publ. ordinarius, Reg. Societ. Litt. Teut. Regiom. membrum honorarium. - Mosquae [Moskva]: Typis Universitatis Caesareae Moscvensis, 1771. - $28 \mathrm{p}$.

29. Reichel G. De optimis civium frequentiam augendi modis: Panegyricus augustissimae monarchae Catharinae II totius Russiae imperatrici et autocratori etc. in solemnitate publica ad recolenda regni auspicia ab Universitate Caesarea Moscvensi d. 30. Jun. 1766. celebrata dictus a Joanne Godofredo Reichel historiarum professore publico ordinario Universitatis bibliothecario et Societatis L.L.A.A. Lipsiensis membro. — Moscvae [Moskva]: Typis Universitatis Caesareae Mosquensis, 1766. - 19 p.

30. 240 лет первой публикации по политической науке в Московском университете. - URL: http://old.polit.msu.ru/department/news/183/ (дата обращения: 08.11.2021). 


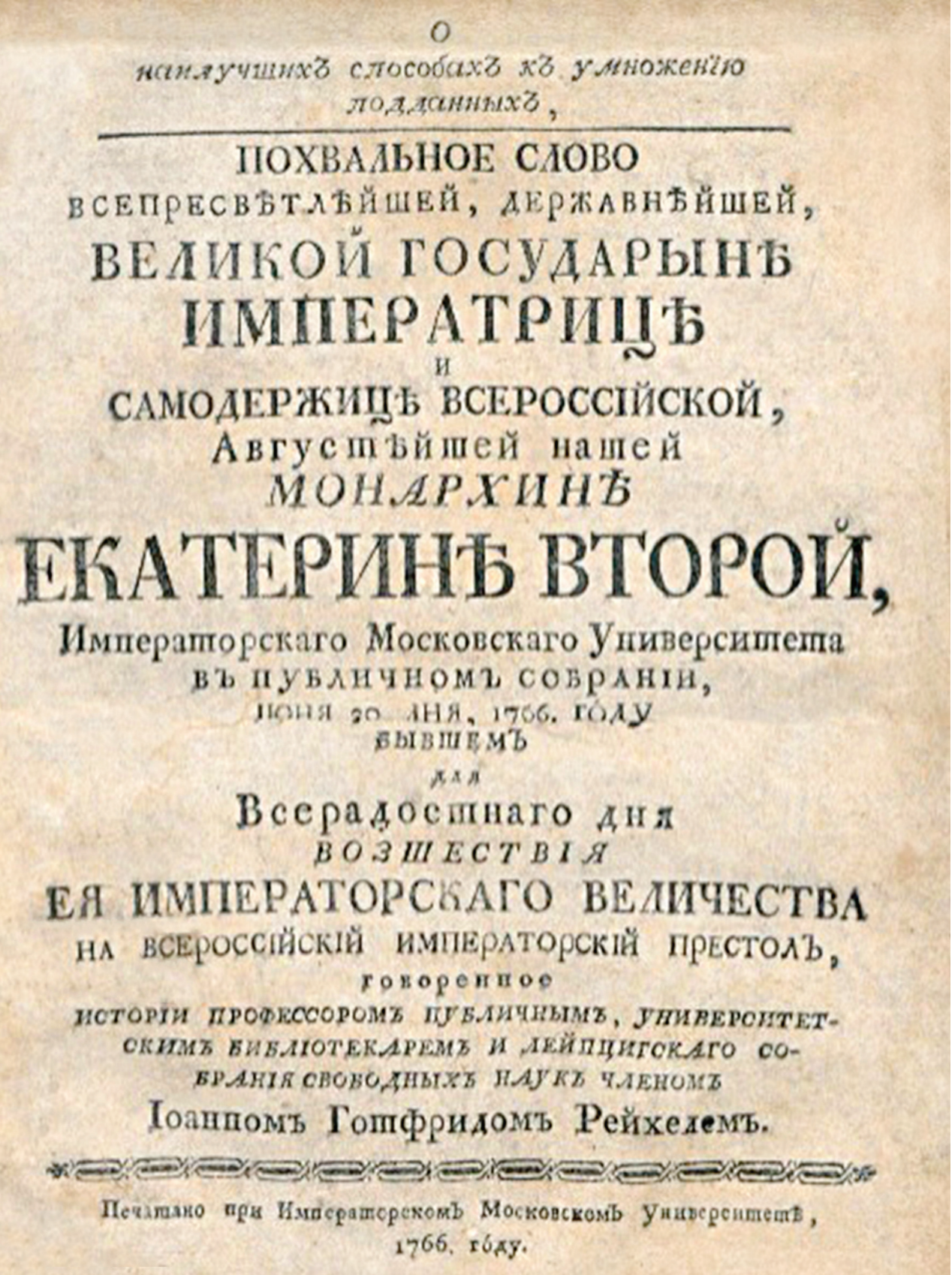




\section{$O$ \\ наилучших способах к умножению подданных}

\section{ПОХВАЛЬНОЕ СЛОВО}

ВСЕПРЕСВЕТЛЕЙШЕЙ, ДЕРЖАВНЕЙШЕЙ, ВЕЛИКОЙ ГОСУДАРЫНЕ ИМПЕРАТРИЦЕ

И

САМОДЕРЖИЦЕ ВСЕРОССИЙСКОЙ,

Августейшей нашей МОНАРХИНЕ

\section{ЕКАТЕРИНЕ ВТОРОЙ,}

Императорского Московского университета

В ПУБЛИЧНОМ СОБРАНИИ, ИЮНЯ 30 ДНЯ 1766 годА

БЫВШЕМ

для Всерадостного дня

\section{ЕЕ ИМПЕРАТОРСКОГО ВЕЛИЧЕСТВА}

НА ВСЕРОССИЙСКИЙ ИМПЕРАТОРСКИЙ ПРЕСТОЛ,

говоренное

ИСТОРИИ ПРОФЕССОРОМ ПУБЛИЧНЫМ, УНИВЕРСИТЕТСКИМ БИБЛИОТЕКАРЕМ И ЛЕЙПЦИГСКОГО СОБРАНИЯ

СВОБОДНЫХ НАУК ЧЛЕНОМ

\section{Иоанном Готфридом Рейхелем}

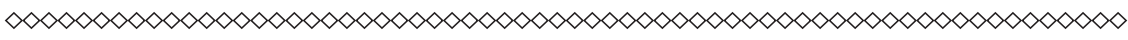

Печатано при Императорском Московском университете ${ }^{1}$ 1766 год

\footnotetext{
1 Текст публикуется по изданию, которое хранится в Российской государственной библиотеке: О наилучших способах к умножению подданных: похвальное слово всепресветлейшей, державнейшей, великой государыне императрице и самодержице всероссийской, августейшей нашей монархине Екатерине Второй, Императорского Московского университета в публичном собрании июня 30 дня 1766 года бывшем для всерадостного дня восшествия Ее Императорского Величества на всероссийский императорский престол, говоренное истории профессором публичным, университетским библиотекарем и Лейпцигского собрания свободных наук членом Иоганном Готфридом Рейхелем. - М.: Печ. при Имп. Моск. ун-те, 1766. - 20 с.
} 
Прославившийся между британцами своим учением ИСААК ВОСС ${ }^{1}$, из любви к особенным мнениям не доволен будучи учеными людьми своего века, по смерти своей испытал, что тот, кто мнения других отвергает, мало или никого и не находит, кто бы с ним самим хотел согласиться. Умолчим о его дерзости в исправлении древних писателей, оставим бывшие его с ГУМФРИДОМ ГОДИЕМ ${ }^{2}$, КЛАВДИЕМ САЛЬМАЗИЕМ ${ }^{3}$, ЯКОВОМ ГРАНОВИЕМ, РИЧАРДОМ САЙМОНОМ ${ }^{4}$ И ДРУГИМИ ссоры, смертью оных прекращенные. Большей важностью было его мнение, которым утверждал, что вселенная в древние времена содержала в себе больше жителей, нежели ныне, и что сама Европа в нынешние времена людей едва имеет тридцать миллионов. Сие из излишнего к древности почтения происшедшее мнение упорно защищал он в книге разных своих примечаний (*Londini 1686).

У изрядных писателей в обыкновении было говорить, что царства и города наподобие людей рождаются, растут, стареют и напоследок умирают; ибо, кроме ГЕРОДОТА ${ }^{5}$, ЦИЦЕРОНА ${ }^{6}$,

1 Исаак Восс (лат. Isaac Vossius, 1618-1689) нидерландский филолог и библиофил, собиратель рукописей. Занимался изданием и комментированием древних литературных памятников.

2 Гумфрид (маркиз Готии) (фр. Onfroi, нем. Humfried, ум. после 876 г.).

3 Клавдий Сальмазий (Клод де Сомез, фр. Claude de Saumaise, 1588-1653) - французский писатель, автор многочисленных сочинений по философии, юриспруденции и филологии.

4 Вероятно, имеется в виду Ричард Саймон (Richard Simon, 1638-1712) - французский священник, член ораторианцев, библейский критик, востоковед и полемист.

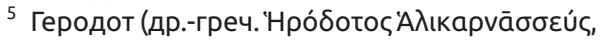
около 484 г. до н.э. - около 425 г. до н.э.) - древнегреческий историк, автор первого сохранившегося трактата «История». Геродота, по меткому замечанию Цицерона, называют «отцом истории».

${ }^{6}$ Цицерон Марк Туллий (лат. Marcus Tullius Cicero, 106-43 гг. до н.э.) - римский государственный деятель, оратор и писатель, впервые сделавший латинский язык полноправным средством выражения философских идей.
ВЕЛЛЕЯ ПАТЕРКУЛА ${ }^{7}$, и другие (**PETRI FABRI Dissertat I. Semestr viiii) употребляли сие сравнение и государства представляли под образом человека рождающегося, в совершенной возраст приходящего, стареющегося, болящего, умирающего и как бы оживающего. Сие сравнение, вышед из своих границ, неосторожных древности любителей до того довело, что начали верить, будто в настоящей сего света старости всех вещей естество не токмо ослабло и истощало (*COLUMELLA. De re rustica. Lib. I. P. 383. Edit. GESNER), но и число живущих в нем людей несказанно уменьшилось.

Спорящие о бывших в древнем свете государствах, народах, обычаях, науках и происходивших тогда делах в мнениях своих по большей части разделились на две стороны, из которых одни из почтения к древности в древнем свете ничего не нашли, кроме великого, удивительного и непостижимого, а другие превосходство своего века предпочли сомнительным древнего света похвалам. То же примечено нашими предками в учиненном ИСААКОМ ВОССОМ вопросе о множестве живших в первые века мира сего людях, ибо они ВОССОВЫ причины рассматривали, остаткам древности дивились, уступили, что пространные и великие тогда были государства, и не противоречили, что войска в древние времена были многочисленнее нынешних, но другие из ограниченного о вселенной знания из пустых и необитаемых в тогдашнее время в Европе земель и самого ВОССОВА наших времен презрения противное тому заключали. Ибо кто может принять ВОССОВЫ на то доводы, которыми он соединенным Нидерландам два, Франции пять, а России только три миллиона жителей приписывает. Гораздо скромнее был

7 Веллей Патеркул (лат. Velleius Paterculus; 20 или 19 г. до н.э. 一 после 30 г. н.э.) - римский историк, написал и опубликовал сочинение «Римская история» (в двух книгах). 
ДИОДОР СИКУЛЬ ${ }^{1}$ (**Libr. II. Pag. 118. Edit. WESSELING), который, плодородие Азии и Италии превознесши похвалами, свидетельствует о своих временах, что вся Италия числом людей ни с одним из азиатских народов сравниться не может, употребляя сие извинение, дабы читатели из нынешних градов опустошения не заключали о прежнем числе народа. Хотя древним писателям и представлялись тогда перед глазами великие войска, по объявлению историков в Семирамидины ${ }^{2}$, Ниновы ${ }^{3}$, Ксерксовы ${ }^{4}$, Дариевы ${ }^{5}$ и других азиатских монархов времена бывшие, но из сего ничего не следует, кроме того, что в те времена в Азии было превеликое изобилие в народе, когда в то же самое время прочие части света были, может быть, без жителей, которыми оные после того переселением народов наполнены.

Итак, мы по справедливости удивляемся, каким образом произошло,

1 Диодор Сикуль (Сицилийский) (др.-греч.

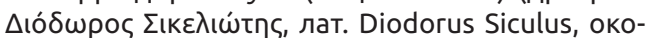
ло 90 г. - 30 г. до н.э.) - автор «Исторической библиотеки» (др.-греч. ВıßАıӨп́кп ібторıки́), включающей сведения о всемирной истории от сотворения мира до Галльской войны Цезаря, то есть до 60 г. до Р.Х. Из 40 книг полностью сохранилось только 15 (I-V и XI-XX).

2 Семирамида (аккадское - Саммурамат, Шамерамат), царица Ассирии, жена Шамши-Адада V (823-811 гг. до н.э.) и мать Адад-нерари III (Ададнирари III, 810-783 гг. до н.э.). В аккадской и древнеармянской мифологиях легендарная царица Ассирии, супруга царя Нина, убившая его хитростью и завладевшая властью. Античные авторы приписывали Семирамиде основание Вавилона и владычество над всей Азией.

${ }^{3}$ Нин (др.-греч. Nívoc или Nîvoc) - персонаж древнегреческой мифологии, первым из азиатских царей начал вести войны с соседями и покорил их. Считается, что никакого Нина в реальности у ассирийцев не было, а под этим именем, вероятно, отражается образ Семирамиды.

${ }^{4}$ Ксеркс (др.-перс. Хшаяршан — «герой среди царей», ок. 522-465 гг. до н.э.) - персидский царь из династии Ахеменидов, сын Дария I, правил с 486 по 465 г. до н.э.

5 Дарий I (др.-перс. Дараявауш - «добронравный») - царь Персии в 522-486 гг. до н.э., при его правлении Персия простиралась от Египта до Индии. что разумнейший муж MOHTECKьE ${ }^{6}$ в преизрядном своем сочинении о законах ${ }^{7}$ (*Esprit des loix. Lib. XXIII. Сap 18. Sequ) ВОССОВо мнение столь охотно принять и в «Персидских письмах» ${ }^{8}$ (**Lettres persanes. Epist. 98) подтверждать мог, что в свете ныне едва пятидесятая часть жителей находится против времен Юлия Цезаря9 ${ }^{9}$. Сие великого мужа мнение, многими опроверженное (***Bibliotheque raifonuee. Tome XXXXIII. Part. 2), возбудило тот вопрос с ВОССОМ как бы погребенный, и двум мужам, в сем роде наук искуснейшим, подало случай о сей материи рассуждать на обе стороны. ВАЛЛАЦИЙ, Эдинбургского философического общества ${ }^{10}$ член и покойного великобританского короля из придворных духовных особ, написал рассуждение (****На французском языке издано в Лондоне, 1754, см. Bibliotheque des scientes. Tome IIII. Part. I. На немецком

${ }^{6}$ Монтескье Шарль Луи де Секонда (16891755) - французский писатель, философ, один из крупнейших представителей французского Просвещения, член Французской академии (1728 г.). Один из первых авторов, которого Екатерина II начала с интересом читать (см.: Екатерина II. 3аписки / Императрица Екатерина Вторая. - М.: Захаров, 2021. - С. 60, 196).

7 «О духе законов» (фр. De l'esprit des loix) трактат по политической философии за авторством Монтескье, опубликованный анонимно в Женеве в 1748 г.; одна из ключевых работ эпохи Просвещения. "Наказ» Екатерины II (наставления для депутатов Уложенной комиссии 1767-1769 гг.) во многом заимствован именно из текста Монтескье «О духе законов».

8 «Персидские письма» («Lettres persanes») роман в письмах Шарля Луи де Монтескье. Это первое художественное произведение Монтескье. Роман завершен в 1721 г.и тогда же впервые анонимно опубликован в Амстердаме.

9 Гай Юлий Цезарь (Gaius Iulius Caesar) (10044 гг. до н.э.) - римский политический и государственный деятель, полководец, оратор, писатель, один из основателей Римской империи.

10 В 1737 г. от Эдинбургского медицинского общества отделилось Эдинбургское общество по развитию искусств и наук и особенно знаний о природе. В 1738 г. название было изменено на Эдинбургское философское общество, которое в свою очередь было преобразовано в 1783 г. в Эдинбургское королевское общество. 
языке находится Гамбургского магазина в 23 части) о числе людей, бывших в древние и новейшие времена, в котором собранными через великое чтение из многих писателей свидетельствами защищает ВОССОВО мнение. Против сего ученого рассуждения другое, не меньше ученое и особливым знанием украшенное рассуждение ж издал ДЭВИД ЮМ ${ }^{1}$ (*****Discours politique par Мr. HUME. Tome 1. Pag. 118. На немецком языке находится Гамбургского магазина в 10 части), которое между политическими его сочинениями десятым считается и в котором он приведенные ВАЛЛАЦИЕМ свидетельства разбирает с великим рассмотрением, о всех его доводах рассуждает с такой остротой разума, что читатели по прочтении обоих рассуждений остаются в несносном сомнении.

Многим покажется тот труд бесплодным, а особливо тем, которые из изыскивания и исследования мест классических писателей малой или никакой не ожидают пользы, в рассуждении важнейших наук происходящей. Но сии ежели так рассуждать станут, то они покажут себя худыми сих вещей знатоками, когда самый опыт научил, что такие труды не только принесли много просвещения к истолкованию сей материи, но и другим, в политических науках упражняющимся, дорогу показали, по которой они в пользу государства изобрели весьма важные и полезные истины. Ибо как те, которые писали о начале и распространении наук между первыми сего света жителями, из излишнего к древности почтения превзошед границы и объяты будучи удивлением о всякой вещи, казалось,

\footnotetext{
1 Возможно, имеется в виду Дэвид Юм (англ. David Hume; 1711-1776) - шотландский философ, родился и воспитывался в шотландском городе Эдинбурге. Представитель эмпиризма и агностицизма, один из крупнейших деятелей шотландского Просвещения. Работал библиотекарем, состоял на государственной дипломатической службе, был профессором университета.
}

что они в свое время неприятный труд предпринимали, который потомкам, напротив того, был тем полезнее, когда нынешние люди из собранной о разных вещах материи приметили дорогу и способ, через которые наука и художество между столь многими народами, древностью от нас отдаленными, произведены, умножены и до такого возведены совершенства; и из того научившись, издали в свете преизрядные сочинения о началах законов, наук и художеств; равным образом и издавшие ученые, и примечания достойные мнения о множестве людей, в древние с нынешними временами различном, во многих внимание возбудили, которые из сих споров по различной народов природе, по разным между оными обрядами и обычаями изыскали самих людей размножение, по законам естества происходящее, и потом своими рассуждениями через сравнение разных между собой примеров показали, в какой пропорции размножение людей бывает в свете.

К рассмотрению сей материи особенное старание приложили славные мУЖИ: ГРАУНТ ${ }^{2}$, АРБЕТНОТ $^{3}$, ПЕТТИ $^{4}$,

2 Джон Граунт (англ. John Graunt; 16201674) - английский ученый, родоначальник демографии, начал разрабатывать методы статистики и переписи населения, считается первым экспертом в области эпидемиологии. В 1662 г. в Лондоне была опубликована его книга «Естественные и политические наблюдения, перечисленные в прилагаемом оглавлении и сделанные на основе бюллетеней о смертности. По отношению к управлению, религии, торговле, росту, воздуху, болезням и другим изменениям названного города. Сочинение Джона Граунта, гражданина Лондона».

3 Джон Арбетнот (англ. John Arbuthnot; 16671735) - шотландский врач, представитель эпохи Просвещения. На основе статистических данных Арбетнот обратил внимание на то, что рождается больше мальчиков, чем девочек. Объяснил это мудростью Провидения, так как мужчины чаще гибнут молодыми.

${ }^{4}$ Уильям Петти (англ. William Petty; 16231687) - английский экономист и статистик. Входил в число зачинателей классической политической экономии. Один из учредителей Лондонского королевского общества и председатель 
КИНГ ${ }^{1}$, ДЕРЕМ ${ }^{2}$, НЬИВЕНТИДЖТ ${ }^{3}$, КЕРСЕБОМ ${ }^{4}$, СТРИК, ЮСТИ $^{5}$ и знатнейший

Дублинского философского общества. В своих работах, в частности в таких, как «Трактат о налогах и сборах» (1662), «Слово мудрым» (1665), «Политическая анатомия Ирландии» (1672), «Разное о деньгах» (1682), «Политическая арифметика» (1683), заложил основы политической экономии и статистики.

1 Грегори Кинг (англ. Gregory King, 16481712) - английский ученый, занимавшийся изучением генеалогии, представитель школы политической арифметики. Написал труд «Естественные и политические наблюдения и выводы о положении и условиях существования Англии» (1696). Проанализировал упущенные возможности прироста капитала и населения из-за эпидемий, войн и пожаров, а также осуществил первый опыт перспективного расчета населения.

2 Уильям Дерем (англ. William Derham; 16571735) - английский священник, натурфилософи физик, первым измерил скорость звука. В 1696 г. написал труд «Artifical Clockmaker» («Искусственный часовщик»). В 1713-1714 гг. написал первые два труда цикла: «Физико-теологию» и «Астротеологию» - это телеологическая аргументация существования и неотъемлемых качеств Бога. В 1730 г. завершил цикл написанием «Христотеологии".

3 Бернар Ньивентиджт (Nieuwentijdt, или Nieuwentyt; 1654-1718) - голландский философ, математик, врач, магистрат, мэр (Пурмеренд) и теолог. Его главный труд - «Истинное использование созерцания мира» (1715).

4 Биллем Керсебом (Kersseboom; 16911771) - голландский статистик. Занимался вопросами политической арифметики. В 17371742 гг. опубликовал семь полемических 6рошюр, которые сыграли заметную роль в развитии количественного изучения массовых явлений, В том числе и демографических процессов. Автор так называемой Лондонской таблицы смертности, содержавшей данные о вероятной продолжительности предстоящей жизни новорожденных английской столицы. Исследовал возможность определения численности населения по данным о рождениях и смертях, исходя из предположения, что число ежегодных рождений в стране величина постоянная.

${ }^{5}$ Иоганн Генрих Готтлоб фон Юсти (нем. Johann Heinrich Gottlob von Justi; 1717-1771) ведущий немецкий политэкономист XVIII века. Научную деятельность посвятил учению о внутреннем государственном управлении, имеющем целью всеобщее благо. Выдвинул идеи экономического толка с целью поддержки роста населения. На русский язык переведены следующие работы Юсти: «Существенное изображение есте- между оными почтенный ЗЮсмИЛьХ ${ }^{6}$, которых тяжким и с первого виду неприятным трудом не токмо законы о размножении людей преизрядно истолкованы, но и наилучшие способы к умножению числа жителей объявлены, когда ученейшие сии люди из сравнения наших времен с прежними приметили, что было причиной размножения или уменьшения жителей. Из чего произошел знатный вопрос о размножении подданных, в решении которого разными способами с великим прилежанием употреблено уже более десяти лет. И подлинно в изъяснении оного до пота трудились славные в ученом свете МУЖИ МИРАБО 7 , ЗЮСМИЛЬХ, ЮСТИ, БИЛЬФЕЛЬД ${ }^{8}$ и другие, коих мы здесь не упоминаем.

ства народных обществ и всякого рода законов» (перевод: Авраам Волков. СПб., 1770 и М., 1802), «Основание силы и благосостояния царств, или Подробное начертание всех знаний, касающихся до государственного благочиния» (перевод: Иван Богаевский. СПб., 1772-1778), «Торгующее дворянство» (перевод: Денис Фонвизин. СПб., 1766).

6 Иоганн Петер Зюсмильх (нем. Johann Peter Süßmilch; 1707-1767) - пастор, ученый и общественный деятель, занимает видное место в истории статистики. В своем основном труде «Наблюдения божественного порядка в изменениях человеческого рода, доказанного из рождения, смерти и размножения такового» (1741 и 1761) объясняет закономерности рождаемости и смертности. Один из первых, кто начинает развивать научное, математическое направление статистики. Будучи богословом, многое объясняет божественным порядком. Осуществил расчет примерной численности населения.

7 Возможно, имеется в виду Виктор Рикети де Мирабо (фр. Victor Riqueti, marquis de Mirabeau; 1715-1789) - французский экономист. Разделял идеи меркантилистов, затем примкнул к физиократам. Выступал за развитие земледелия и расширение внешней торговли, считая их основными факторами роста благосостояния.

8 якоб Фридрих фон Бильфельд (нем. Jakob Friedrich von Bielfeld; 1717-1770) происходил из семьи гамбургских купцов. Получил образование в Лейдене. В 1732 и 1735 г. совершил образовательные поездки во Францию и Англию, во время которых познакомился с Монтескье. Советник Фридриха Великого, куратор прусских университетов (1747). Его главная работа - «Institutions Politiques» (1760), посвященная государственному управлению, выдержала 16 изданий. На рус- 
И как принял я намерение в настоящем торжественном собрании говорить о сей материи, то не подумайте, почтеннейшие слушатели, что сие предпринимаю я для того, будто бы вышеупомянутые мужи не совсем сию материю истолковали, весьма малого чего в ней недостает, и то, может быть, нарочно у них опущено; но по большей части для той причины в сем похвальном слове о наилучших способах к умножению подданных говорить бУДУ, что ВСЕМИЛОСТИВЕЙШАЯ НаШа ГОСУДАРЫНЯ АВГУСТЕЙШАЯ ВСЕЯ РОССИИ ИМПЕРАТРИЦА И САМОДЕРЖИЦА собственным высочайшим Своим примером подает нам оные способы. Ибо с самого того временИ, каК ПРЕЩЕДРАЯ МАТЬ ОТЕЧЕСТВА для общего империи благосостояния в правление столь пространного государства вступила, ничего любезнее и ничего дороже не почитает, как благосостояние своих подданных, которое состоит в сохранении и размножении жителей.

Не ожидайте от меня, почтеннейшие слушатели, новых и неслыханных политических наставлений, не требуйте от меня, чтобы я вам сей вопрос, другими уже почти решенный, представил во всей своей обширности, такого пространного рассуждения ни время, ни место не дозволяют, и паче изобилие материи меня принуждает, чтобы я по примеру географов, великие города точками, а реки линиями замечающих, в сем предложении был краток. Но надеюсь, что оратора, наилучшими ВСЕАВГУСТЕЙШЕЙ НашеЙ МОНАРХИНИ ВЫсочайшими способами о размножении

ском языке труд озаглавлен следующим образом: «Наставления политические барона Бильфельда» (1760). Первая часть работы была переведена на русский язык князем Федором Шаховским и опубликована в 1768 г., вторая часть переведена профессором Антоном Барсовым и опубликована в 1775 г. На русский язык «Наставления...» были переведены по инициативе Екатерины II и использовались как учебное пособие по политическим наукам в Московском университете. подданных наученного, благосклонно выслушаете, которой благосклонности от вас, почтеннейшие слушатели, прошу нижайше.

Прежде нежели приступим к самой материи, кратко надлежит ответствовать тем, которые, смотря на примеры древних, сомневались: должны ли государи умножать число жителей? Ибо они слыхали, что у греков было обыкновение, чтобы в республиках определять известное только число (*Guil. Postellus. De Magistr. Atheniens. Ep. I) жителей, которое они не преступали, и чужестранцев охотно в число граждан не принимали. Но и древние республики имели свои недостатки, из предрассужденных мнений иногда происходившие, и состояние оных не было вообще такое, чтобы в наши времена могло быть примером без всякого выключения. Ибо, умолча о других причинах, в самом тех республик расположении бывших, жители греческих республик мало упражнялись в земледелии, но определяли к оному побежденные народы, отправляя сами военную службу, и таким образом, когда войско не могло умножаться, то и число оных чрезвычайно размножать не должно было. Но римляне лучше рассуждали, ибо они побежденные народы с собой соединяли, соединенным давали право гражданства и таким образом не токмо число жителей дивным образом размножали, но и то самое разумно учинили, что Римская республика через сие возрастала и достигала до столь великой степени в своей силе и благополучии. Ибо государство без внутренней силы внутреннего и истинного благополучия достигнуть не может, а внутренняя государства сила не изобилием злата и сребра приобретается, но множеством жителей и граждан, которые всеми силами стараются 06 общей государственной пользе. Итак, ежели старание о благосостоянии государств верховным владетелям должно быть главным законом, то из сего следует, 
что верховные владетели и государи для внутренних сил, к благосостоянию государств необходимо нужных, о размножении числа жителей всеми силами стараться должны.

В размножении же подданных должно наблюдать две вещи: сохранение и размножение жителей, в государстве живущих, и вызывание иностранных через доброе правление, плодородие земли и легкость получать вещи, к жизни потребные, дабы они в таковых границах жилище иметь восхотели. Обе упомянутые вещи никогда получить невозможно, ежели в государстве земледелие пренебрегается. Ибо такое государство, где земледелие и соединенные с ним труды в худом, развращенном или совсем беспорядочном состоянии находятся, ни многих жителей производить и питать, ни от претерпевающих голод и для жизни потребных вещей, не имеющих силу, помощь и благополучие ожидать может. Следовательно, земледелие подает великую помощь к размножению подданных. Ежели есть такие места, в которых люди жить, землю пахать, в ремеслах упражняться и своими трудами вещи, к своему пропитанию и одеянию потребные, снискивать могут, там составляются малые общества, свободные бывают бракосочетания и люди соединенными силами трудятся в снискивании необходимо нужных к жизни вещей и сообщении оных с другими.

Законодавцы древнего света, в учреждении республик о размножении жителей старающиеся, разделяя поля, особенными законами в земледелии упражняться повелевали, да и тем людям, которых республики за учиненные их или чинимые публичные заслуги должны были питать, никакого другого не определяли жалованья, кроме того, которое собиралось с назначенных им для сего пашен и полевых плодов; таким образом, все, к трудам и земледелию возбуждены будучи, всякое старание прилагали к удобрению означенной себе земли, дабы получить с оной плоди потребное для пропитания. Да и жизнь деревенская у древних за стыд не почиталась. Послушаем МАРКА KATOHA ЦЕНСOPA ${ }^{1}$ (*COLUMELLA. De re rustica. Lib. I. P. 386. Edit PESNER), великого в свое время у римлян мужа, который, свидетельствуя о своих предках, говорит: «Когда доброго мужа хвалили, то хвалили доброго земледельца и доброго сельского жителя, ибо такая похвала почиталась за самую большую».

Итак, древние по справедливости в порок вменили законодавцам, что они в учреждении республик и в сочинении законов, пренебрегши земледелием, более смотрели на военное состояние, которую хулу понесли на себе Минос ${ }^{2}$ и Ликург ${ }^{3}$. То же подтверждают исторические писатели, по объявлению которых и критяне, и спартанцы пренебрегали земледелием, оставив оное слугам, с которых ежегодную дань собирали. Кроме греков, и другие также народы, трудившиеся прежде в земледелии, в последующие времена оное презирать начали, как подлое и великих мужей недостойное, а особливо в те времена, в которые от простой жизни к пышностям и роскошам уклонились, и, наскучив спокойствием, не довольны будучи свои имением, желая чужого богатства, возбудили войны, себе и другим пагубные. От сего в отечестве своем о земледелии нерадения, от сего простой жизни презрения человеческий

1 Марк Порций Катон Цензор (лат. Мarcus Porcius Cato Censorius, Cato Мајor, около 234 г. до н.э. - 149 г. до н.э.) 一 полководец и политический деятель Древнего Рима, первый латинский прозаик. Автор трактата «Земледелие» (или «О сельском хозяйстве») - самое древнее произведение на латинском языке по истории сельского хозяйства.

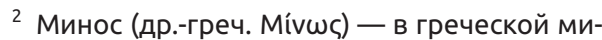
фологии - критский царь, один из трех сыновей Зевса и Европы. Согласно преданиям, жил за три поколения до Троянской войны.

3 Ликург (др.-греч. ^uкои̂рүо૬) - легендарный спартанский законодатель (IX-VIII вв. до н.э.), которому приписывают создание институтов спартанского общественного и государственного устройства (герусии, апеллы), раздел земель между спартиатами. 
род учинился склонным к пышности и гордости, отчего произошел ущерб и расточение собранного великим старанием имения, от расточения бедность и долги, от долгов, которых заплатить были не в состоянии, ужасные об истреблении республик заговоры, от сих заговоров междоусобные брани, от междоусобных браней изгнание богатых, разорение провинций, уменьшение человеческого рода, глад, мор и крайняя бедность. Имеете, слушатели, печальный виддревнего Рима, от своей простоты к пышности, от земледелия к праздности и через то в превеликое несчастие пришедшего. За несколько перед сим слышали мы почтенное о достоинстве земледелия Катоново свидетельство; кто не удивится по прошествии невступно еще двух веков совсем переменившимся римлянам, В роскоши, лености и бедности погруженным, на неплодородие земли жалующимся? Послушаем другого о земледелии писателя КОЛУМЕЛЛУ ${ }^{1}$, на бесплодие земли приносимые жалобы (*CATO. De re rustica. Ab initio. Pag. 2. Edit. GESNER) с великим негодованием за презрение земледелия отвечающего: «Не думаю я, — говорит он, - чтобы сие нам приключилось от неумеренности, но произошло сие от нас самих, ибо мы земледелие самым негодным рабам, как палачам на пагубу, отдали, которое всяк наилучший из наших предков отправлял рачительно. И не могу я довольно надивиться, для чего желающие хорошо говорить столь тщательно избирают оратора, чтобы подражать его красноречию, наблюдающие меру и числа в приятной науке подражают учителю, старающиеся о музыке и танцевании со всяким рассмотрением изыскивают в голосе и в пении искусного певца, в движении тела танцевального

1 Луций Юний Модерат Колумелла (лат. Lucius Iunius Moderatus Columella; 4 г. - около 70 г. н.э.) - римский писатель, автор сочинения "О сельском хозяйстве» (лат. «De re rustica»), которое состоит из 12 книг, а 10-я книга о садоводстве - в стихах. мастера; хотящие строиться - плотников и архитекторов, вверяющие морю свои корабли - знающих кормщиков, приуготовляющиеся к войне в храбрости и в воинских делах искусных призывают; и, чтобы не упоминать о всем, всякий в том учении, в каком упражняться хочет, разумного предводителя употребляет; наконец, всяк старается иметь разуму и добродетелей мудрого наставника - одно земледелие, которое, без сомнения ближайшее и будто сродством с мудростью соединенное, как в учащихся, так и в учащих имеет недостаток. Ибо я не только слышал, но и сам видел, что риторские и, как я уже сказал, геометрические, музыкальные и, что более удивления достойно, самых гнуснейших пороков училища, также вкуснее готовить кушанье и убирать волосы мастера и поныне находятся, а земледелия ни учителей, ни учеников не знаю. Без забавных искусств также и без стряпчих города прежде сего были и впредь будут благополучными, а без земледельцев ни быть, ни питаться смертные не могут».

Так говорил КОЛУМЕЛЛА, с великой прискорбностью на свои времена жалуясь, но и самых дел сбытие доказало, что он о Римской республике, которая через наступающее из презрения к земледелию расточение и гражданские возмущения бесчисленных преизрядных граждан лишилась, справедливое имел мнение. Ибо в те времена, в которые земледелие было в чести, римские дела не токмо были в преизрядном порядке и процветали, но и не из весьма больших провинций, о земледелии тогда весьма старавшихся, наподобие пчелиного роя выходили многочисленные войска, а те же самые провинциИ в ДИОДОРОВЫ и КОЛУМЕЛЛИНЫ времена по большей части были пусты и необитаемы.

Но на что мне в книгах древних писателей искать доказательство о великой надобности земледелия в умножении подданных? Есть на то и домашние свидетельства. Зачем мне здесь вспо- 
минать о наблюдении дел экономических, почти во всех европейских государствах ныне восстановленном? Сама Россия представляет очевидный нам пример не только для зрения, но и для подражания. Ибо с того времени, как любящие отечество мужи приняли намерение надобность и пользу экономии жителям выхвалять и земледелие в государстве, как первое основание в умножении народа, своими наставлениями, советами и примерами распространять и оное, учредив Экономическое общество ${ }^{1}$, в совершенство приводить единодушно стараться начали, то никто не мог сомневаться о том, чтобы оные мужи, заняты и обременены будучи важными государственными делами, земледелие в государстве не почли за самую нужную вещь, когда они при столь многих трудах время, для отдохновения им определенное, самопроизвольно из единого усердия употребили на исправление экономии. Итак, великие те об общей отечества пользе попечители что иное от ЕЕ ИМПЕРАТОРСКОГО ВЕЛИЧЕСТВА ОЖИДаТЬ могли, как всемилостивейшее на то благоволение, от жителей похвалу, а от потомков благодарность? Сие самое учреждение, при владении ВСЕМИЛОСТИВЕЙШЕЙ МАТЕРИ ОТЕЧЕСТВА благополучно начавшееся, докажет ПотомКам, что ЕКАТЕРИНА ВТОРАЯ, по премудрому Своему в избирании

\footnotetext{
1 Императорское Вольное экономическое общество к поощрению в России земледелия и домостроительства - первая в России независимая научная и общественная организация, старейшая общественная организация Европы и мира, основана Указом императрицы Екатерины Великой 11 ноября (31 октября по старому стилю) 1765 г. Задачи, методы работы, устав организации были разработаны М.В. Ломоносовым во «Мнении об учреждении государственной коллегии (сельского) земского домостроительства» и группой ученых. У истоков общества стояли Роман Воронцов, Григорий Орлов, Иван Чернышев, Адам Олсуфьев и др. Общество издавало книги, журналы, проводило выставки, было научно-практическим центром по распространению оспопрививания. Подробнее о Вольном экономическом обществе Pоссии: http://www.veorus.ru.
}

умножающих благополучие отечества способов рассуждению, науки, общему житию и каждому владению весьма полезные и к истинному государственному благополучию служащие, привела в прежнее свое достоинство. Сия похвала, от самого превосходного правления происходящая, есть истинная и бессмертная и народы в удивление о6 АВГУСТЕЙШЕЙ И ПРЕМУДРЕЙШЕЙ нашей МОНАРХИНЕ восхищает больше, нежели все подкупленных древних ласкательства.

Сего о первом умножении подданных способе довольно.

Самый опыт научает нас, что земледелию ничто так не препятствует, как война, хотя бы она против неприятелей и не в наших пределах была производима или, от неприятелей нам нанесенная, была отвращаема, ибо земля тогда пустеет и земледельцы бывают без дела. Коль великий страх объемлет деревенских жителей? Коль великий урон приключается в домостроительстве? Коль великие разграбления? Для кого сеют? Для кого жнут? Земледельцы в обыкновенных и в известное время отправляемых трудах упражняться не могут от всегдашних помешательств, сверх которых иногда неприятелю должно служить, а наконец, что часто случается, идти в рекруты. Такое смятение и бедное состояние человеческих дел не только число жителей не умножает, но и живущих в отчаяние жизни приводит, от бракосочетания отвлекает, размножению препятствует и число подданных весьма уменьшает.

Почему не могу довольно надивиться весьма остроумному мужу МИРАБО (*L'ami des hommes. Tome II), который в своей книге, «Друг людей» ${ }^{2}$ называемой, полагает, что война размножению народа нимало не препятствует, только бы земледелие не было остановле-

2 В 1756 г. Виктор Рикети де Мирабо выступил с сочинением «Друг людей» (Ami des hommes). Мирабо придавал большое значение земледелию как основному источнику благосостояния государства. 
но. Но, чтобы без обиды такого мужа сказать, условие полагает он невозможное, которым опровергается его мнение. Самые войны, вне Франции бывшие, МИРАБО в том противоречат, ибо по выведении на войну бесчисленного множества жителей не пуста ли земля стояла? Последовавшей за границами столь многих тысяч смертью не умалилось ли число жителей? По разрушении столь многих браков не воспрепятствовано и не истреблено ль было размножение народа? Война, недавно погашенная, сколь сильные подает нам доказательства, что мир есть наилучшее средство к умножению народа! Отвращается дух возобновлять в памяти прошедшие несчастья: один только приведу пример, из которого ясно усмотреть можно, что война размножению жителей препятствует. Всем известно, что победоносное российское оружие Пруссию покорило, а в победе такая наблюдаема была умеренность, что трудно определить, урон ли оному государству причинили победители или более защищение? Бедствия ли, за войной следующие, нанесли или от насильств и бедствий, которыми прочие провинции в то время были угнетаемы, защитили и сохранили? Однако ж при всем том победителей человеколюбии и милосердии оные времена служат доказательством, что война размножению подданных препятствует. Ибо ежели мы справимся с Кенигсберскими записками, число новорожденных и умерших показывающими, то увидим, что в 1755 году в сем городе родилось две тысячи двести тридцать два, а умерло тысяча девятьсот восемьдесят семь человек; следовательно, число вновь народившихся людей есть больше, нежели умерших; а в 1758 году родилось тысяча двести тридцать пять, а умерло три тысячи четыреста двадцать два человека: итак, в сем году двумя тысячами ста восьмьюдесятью семью человеками умерло больше, нежели родилось. Но какой бы урон оказался в тех городах, в которых по- бедоносное оружие утеснило граждан, воспрепятствованное уже земледелие совсем истребило, купечество привело в замешательство и ужасную дань наложило на побежденных! Хотя ничего такого Пруссия не претерпела, однако приведенное нами свидетельство представляет мир как наилучший способ к умножению подданных.

Но сколь много мы обязаны ВСЕАВГУСТЕЙШЕЙ НашЕЙ МОНАРХИНЕ ЕКАТЕРИНЕ ВТОРОЙ, даровавшей нам мирное житие, которое благодарной мыслью Богу и Ей приписываем! Наслаждаемся миром внутренним и внешним, из которого проистекает нам спокойствие, из спокойствия благосостояние, из благосостояния благополучие, из всего сего приращение подданных.

Но столь велико верховных правителей попечение, что хотя бы они, с одной стороны, благосостояние своих подданных совершенно предохранили, но, с другой, еще большее и важнейшее требуется. Пусть процветает земледелие, пусть наслаждаются подданные миром и тишиной, многие еще остаются бедствия, которые бедность смертных преодолевать и промысл правителей отвращать долженствует. Естество человеческое к повреждению склонно и многим болезням и слабостям подвержено, к которым сверх сего присовокупляются часто обстоятельства, по состоянию времени и места трудные и умножению народа вредные. Итак, правители должны премудрыми учреждениями предохранять подданных здравие, и если желают число оных сохранить и умножить, то надобно им наблюдать, чтобы от неискусных врачей, без всякого наказания жизнь подданных прекращающих, в обществе не произошло великого урону. В самые еще древнейшие времена первые законодавцы признали, что врачебные учреждения к сохранению и размножению жителей необходимо нужны. Египет, плодородием своим испытателей естественных вещей в 
древние времена в удивление приведши, подает нам сему пример. Ибо владетели оного толикое имели попечение о сохранении здравия своих подданных, что публичных врачей на казенном жаловании содержали, которых должность была странствующих и требующих помощи лечить безденежно, в случае приключившихся им припадков. О других сюда принадлежащих узаконениях не упоминаю, как за краткостью времени, так и за тем, что в сей материи освободил нас от труда ученейший автор ${ }^{1}$ бессмертного сочинения "О начале законов, наук и художеств древних народов" (*Vid de l'origine des loix, des arts \& de sciences, et de leurs progres, chez les anciens peuples. Volum. II et III. Libr. III). А таковые к сохранению и умножению народа служащие учреждения нужны суть как для недоумения простых людей и помощи себе от других требующих, так и для трудных, пагубных и смертельных болезней, которые часто весьма распространяются, многих заражают, зараженных умерщвляют и наконец по причинении великого урона пропадают.

Почему великое благодеяние бывает народу, когда учреждаются искусные врачи, которые в слабостях и опасностях больным помогают, болезни вылечивают и тем самым жителей сохраняют. Ежели в древние времена гражданин гражданина за сохранение жизни венчал гражданским венцом, из дубовых листьев сплетенным, и сохранителя через всю остальную жизнь почитал за отца, то сколь великим почтением и сколь великой благодарностью обязаны мы верховным владетелям, которых неусыпным попечением не один подданный, но тысячи оных для благосостояния государства сохраняются. Теперь весьма

1 Вероятно, имеется в виду Антуан Ив Гоге (фр. Antoine-Yves Goguet, 1717-1758) - французский историк, правовед, подвижник науки, автор труда «Происхождение законов, искусств и наук и их прогресс у древних народов» (1758). бы пристойно превознести похвалаМИ ВСЕМИЛОСТИВЕЙШЕЙ МАТЕРИ ОТЕЧЕСТВА, ВЕЛИКОЙ НашеЙ ГОСУДАРЫНИ ЕКАТЕРИНЫ ВТОРОЙ пРОМЫСЛ О здравии подданных, которым в столь обширном и пространном государстве наиполезнейшими учреждениями о благосостоянии оных столь много провидено, что то ЕЕ попечение, благости и милосердия преисполненное, по достоинству восхвалить не можем. Итак, ссылаемся мы на удивление иностранных, с великими похвалами соединенное, с которым в записках (**Commentar. de res. in scient. nat. et medic, gest voi. XI. Pag. 713,715$)$ о естественных и в медицине происходивших делах, о медицинских АВГУСТЕЙШЕЙ нашей МОНАРХИНИ учреждениях ученому свету радостно объявляют. Не меньше радости ощущаем, когда ту же благость и милость видим в Государе Цесаревиче и Великом Князе ПАВЛЕ ПЕТРОВИЧЕ ${ }^{2}$, АВГУСТЕЙШЕЙ МОНАРХИНИ ДОСТОЙнейшем Сыне, Матерних добродетелей Подражателе, Всероссийском законном Наследнике. Ибо благочестивейший Государь, будучи еще в младых летах, пришел в сожаление о бедности рода человеческого и с великой щедростью и премудростью учредил Публичную больницу ${ }^{3}$, вечный знак Своего благоутробия, и тем самым всем в государстве

2 Павел I (1754-1801) - сын императора Петра III и императрицы Екатерины II. Отец императоров Александра I и Николая I, великих князей Константина Павловича и Михаила Павловича. Воспитывался в раннем детстве императрицей Елизаветой Петровной. 7 ноября 1796 г. вступил на престол после смерти Екатерины II, короновался в Москве 5 апреля 1797 г.

325 сентября 1763 г. по указу Екатерины II в Москве была открыта первая публичная больница. Предыстория: в 1762 г. Екатерина II прибыла в Москву на коронацию в сопровождении сына Павла, который тяжело заболел и затем был вылечен. В память об излечении Павла Петровича было решено открыть в Москве больницу для бедных, которая получила название Павловской. Больница была размещена в загородной усадьбе генерала Глебова, переданной в казну за долги. В настоящее время - Городская клиническая больница № 4. 
подданным довольно доказал, сколь много почитает жизнь человеческую и сколь великую радость чувствует из сохранения оной. Итак, имеем мы в Российской Империи и третье умножения подданных наилучшее вспоможение, то есть попечение о немощных и медицинские учреждения.

К четвертому умножения подданных способу приступаем, который в том состоит, ежели жители имеют случай вступать в супружество. Когда многие земледелием бывают заняты, то от того происходит изобилие и дешевизна в съестных припасах, а мирное время народу подает случай оными довольствоваться и спокойно наслаждаться. В таком состоянии люди в супружество вступают охотнее, нежели тогда, когда земледелие, оставлено будучи, ни праздным людям трудов, ни претерпевающим глад пищи не подает. Ибо голод и недостаток отвращает народ от супружества, коему и военное время противно, в которое всяк старается о себе и бедность других нести не хочет. Итак, разумно делали те государи, которые, обещая честь, награждение и прочие в гражданской жизни преимущества, граждан к супружеству склоняли. Юлианский закон о бракосочетании жителей ${ }^{1}$, в 736 году от создания Рима изданный, свидетельствует, что Август ${ }^{2}$ по нужде сие сделал. Но римляне тех, которые жену и детей

1 Первый римский император Октавиан Август, при котором родился в Вифлееме Иисус Христос, издал ряд законов: lex Julia de adulteriis, закон 18 г. до н.э., устанавливающий наказания за прелюбодеяние, - наказанию подвергаются не только непосредственные виновники, но и попустители. Другой закон 4 г. н.э. - lex Julia de maritandis ordinibus, внесший целый ряд весьма существенных положений в область брачного права. Этот закон был дополнен затем в 9 г. н.э. по предложению консулов Папия и Поппея. Дополнения позднее объединяются с законом под общим именем lex Julia et Papia Poppaea.

2 Гай Юлий Цезарь Октавиан Август (лат. Gaius Iulius Caesar Octavianus; 63 г. до н.э. 14 г. н.э.) - основатель и первый император Римской империи. При нем Рим из республики превратился в монархию (империю). имели, предпочитали перед старейшими, которые без жены и бездетны были. ГЕЛЛИЙ ${ }^{3}$ (*A. Gellius. Noct. L. II. Cap. XV) говорит о сем следующим образом: по седьмой главе Юлианского закона, «позволяется первейшему из консулов брать знаки правления, не тому, который старее летами, но который детей числом больше, нежели его товарищ, или в своей власти имеет, или на войне лишился». Кандидаты, имевшие многих детей, в прошении (*TACIT. ANNAL. LIBR. II) власти и в жребии провинций предпочитались другим и первые подавали свои мнения (**L. 9. C. DE DECUR), скорее в честь происходили, и по числу детей лета им зачитались. Ибо когда от роду меньше двадцати пяти лет, в достоинства производимы не были, то они по своим детям старшинство лет заслуживали, о чем свидетельствует УЛЬПИАН ${ }^{4}$, который против Папиопоппеева закона ${ }^{5}$ о малолетних так гово-

${ }^{3}$ Авл Геллий (лат. Aulus Gellius; не позднее 130 г. - не ранее 170 г.) - древнеримский писатель, автор сборника «Аттические ночи» (лат. Noctes Atticae). В двадцати книгах рассмотрены сотни частных филологических, правовых, философских и прочих вопросов без систематизации, с сопоставлением мнений нескольких авторов. Ценность труда в том, что наследие многих писателей, цитируемых Геллием, не сохранилось до нашего времени. Благодаря его труду в современной лексике закрепились такие слова, как «гуманизм», «классический» и «пролетарий».

4 Домиций Ульпиан (лат. Domitius Ulpianus, 170-228) - римский юрист, внес большой вклад в разработку всех отраслей римского права. Первым дал определение публичного и частного права, а также классическую формулировку абсолютной императорской власти: «Все, что угодно принцепсу, имеет силу закона».

5 Закон Юлия и Папия-Поппея (Lex Julia et Раріа Рорраеа) - термин, принятый в научной литературе для обозначения семейного законодательства римского императора Августа. В названии отражены имена авторов законов - императора Августа (Гай Юлий Цезарь Октавиан) и консулов-суффектов Марка Папия Муила и Квита Поппея Секунда. Является первым примером в истории целенаправленных и последовательных мер в масштабах государства по укреплению семьи и стимулированию рождаемости. Названия всех законов, а также 
рит: «Никто прежде определенного времени через детей от попечителя не должен получать своего имения, ибо CEBEP $^{1}$ говорит, что повелеваемое законами, чтобы число лет по числу детей уступалось, надлежит до чести, а не до получения своего имения». Я умалчиваю о прочем, из чего видеть можно, что множество детей у римлян имело свое награждение и выгодности, так что из особливой владетелей милости право трех детей и тем давалось, которые были бездетны. У греков в похвалу и честь вменялось, ежели отец имел многих детей, о чем свидетельствует ПлУТAPX ${ }^{2}(* * *$ PLUTARCH. THES. VITA, ab initio), который Пелопа ${ }^{3}$ счастливым почитает не только по богатству, но и

их полный текст не установлены. Важнейшие: «Закон Юлия о порядке брака» (Lex Julia de maritandis ordinibus), "Закон о прелюбодеяниях" (Lex de adulteriis), «Закон о расходах на роскошь» (Lex sumptuaria) и «Закон Папия-Поппея» (Lex Раріа Рорраеа). Законы вводили: 1) обязательность брака для представителей сенаторского и всаднического сословий; 2) ряд ограничений в гражданских правах для холостяков и бездетных; 3) преимущества различного рода для всех имевших детей римских граждан, включая женщин (согласно "Закону о трех детях" (Jus trium liberorum) мать троих детей освобождалась от опеки), а также вольноотпущенников; 4) известное усиление власти главы семьи над ее членами; 5) строгие наказания за прелюбодеяния (см.: Демографический энциклопедический словарь. - М., 1985).

1 Северы (лат. Severi) - финикийская (пуническая) династия римских императоров в 193-235 гг., основана Септимием Севером (правил в 193-211 гг.). К Северам принадлежали императоры: Септимий Север (193-211), Каракалла (211-217), Гета (211-212), Гелиогабал (218-222), Александр Север (222-235).

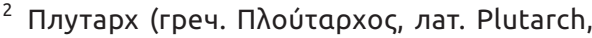
около 46 г. - 120/125 г.) - древнегреческий писатель, историк и философ-моралист, автор «Сравнительных жизнеописаний» и ряда философских произведений, создатель жанра биографии.

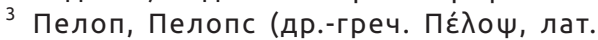
Pelops) - в древнегреческой мифологии герой Пелоп считался сыном легендарного царя Тантала, сына Зевса, и Дионы (или Еврианассы). Являлся основателем рода Пелопидов, по имени которых был назван Пелопоннес («Остров Пелопа») (см.: Адкинс Л., Адкинс Р. Древняя Греция. Энциклопедический справочник. - М., 2008). по многим его детям ${ }^{4}$. То же подтверждают греческие пииты, которые Приамово счастье наибольше в том полагают, что он был отец пятидесяти детей (****De l'origine des loix. Vol. Il. Pag. 59. Edit. Parisia. In 4). Ежели мы несколько повыше приступим к отдаленнейшим временам, то найдем бывший у египтян закон, которым наистрожайше родителям повелеваемо было, чтобы они не токмо своих детей не подкидывали, но и тех бы воспитывали, которых они с рабами родили (*****Diod. SICUL. L. I. Strab. GEOGR. L. XVII). Видите, почтеннейшие слушатели, что древние для размножения жителей гражданам всеми мерами бракосочетание советовали и желаемое удобнее получали, наипаче тогда, когда люди не столь вдавались в роскошь и когда еще воспитание детей без оной не столь было трудно. Ибо роскошь в следующие времена многих отвратила от брака, которую и теперь почти во всех европейских владениях политических дел писатели почитают препятствием к оному. Но я в сей спор не вступаю, ведая, что слово роскошь, разное и неопределенное имея значение, многих привело к тому, что они начали об оном спорить на обе стороны.

4 Плутарх в «Жизнеописаниях» писал следующее: «Пелоп сделался сильнейшим из пелопоннесских царей, благодаря как своему богатству, так и своим детям, он выдал многих из своих дочерей за самых уважаемых граждан, из сыновей же многих поставил царями в различных городах» (см.: Плутарх. Избранные жизнеописания. - Т. 1). Среди детей Пелопа и Гипподамии (дочь Эномая) назывались следующие: Питфей из Трезен, Атрей и Фиест, Алкафой (но не тот, которого убил Эномай), аргонавт Гилпалм, Гиппалкм или Гиппалким, вестник Копрей, разбойник Скирон, аргивянин Эпидавр (которого иногда называют сыном Аполлона), Плисфен, Диант, Кибосур, Коринфий, Гиппас, Клеонт, Аргей, Элин, Астидамия (которую некоторые называют матерью Амфитриона), Лисидика (чья дочь, Гиппофоя, была унесена Посейдоном на Эхинадийские острова и там родила Тафия), Евридика (которую некоторые называют матерью Алкмены), Никиппа, Антибия и, наконец, Архиппа (мать Еврисфея и Алкионы) (см.: Грейвс Р. Мифы Древней Греции / Пер. с англ. К.П. Лукьяненко; Под ред. и с послесл. А.А. Тахо-Годи. - М.: Прогресс, 1992. - 620 с.). 
Которые же выгоду и украшение жизни, от свободных наук происходящие, за роскошь в наши времена почитают и из того наступающую погибель государству предвещают, как пророки, то столь же справедливо говорят и рассуждают, как и наши предки, которые, на роскошь и расточение своих времен принося жалобы, в доказательство справедливости оных приводят в пример французского короля ГЕНРИХА II ${ }^{1}$, который на свадьбе своей сестры был в шелковых чулках, ибо все рассуждается по обыкновениям своих времен.

Но хотя попечение владетелей о бракосочетаниях подданных есть великое вспоможение к размножению оных и великой похвалы достойно, однако если о том только старание прилагается, чтобы жители размножались, а размножающихся воспитание пренебрежено будет, то сии новопроизведенные государствам нанесут больше вреда, нежели пользы. Ибо не довольно, чтобы мы оставили только потомство, но смотреть надобно, какого состояния оно быть имеет. За пренебреженное воспитание и подкидывание детей древние у всех имеют худую славу, хотя греки и римляне иногда и напрасно обвиняемы бывают, будто бы обыкновение подкидывать детей, у них принятое, подтверждено было законами, но противное тому видно из законов, в двенадцати таблицах ${ }^{2}$ содержавшихся.

1 Генрих II (1519-1559) - король Франции с 31 марта 1547 г., второй сын Франциска I, из Ангулемской линии династии Валуа.

2 «Законы XII таблиц» - памятник древнеримского права, приписывается обыкновенно децемвирам (в Древнем Риме коллегия из 10 членов, избираемая для выполнения специальных государственных поручений) и датируется 451450 гг. до н.э. Законы записаны на металлических таблицах и были выставлены на Форуме у здания сената. В 387 г. до н.э. таблицы были уничтожены во время нашествия галлов. Оригинальный текст «Законов XII таблиц" до нашего времени не сохранился, имеются фрагменты из сочинений более поздних авторов. В центре внимания оказываются семейное, наследственное и соседское право (см.: Хрестоматия по истории Древнего
Правительства наших времен не токмо достоинство и честь супружества защищают и воспитания детей от подданных требуют, но и в слабостях человеческих подают вспоможение.

Но нет нигде о воспитании детей столь великого старания, как в России. В сем случае мы без всякого лицемерия с достодолжнейшим почитанием прославляем милосердие АВГУСТЕЙШЕЙ НашеЙ МОНАРХИНИ, которая, не токмо о несчастных людях соболезнуя, для воспитания оставленных родителями детей убежища учредила, в коих оные, из злосчастных детьми империи удостоены будучи, сохраняются, содержатся и воспитываютСЯ, НО ВСЕМИЛОСТИВАЯ И ВСЕЩЕДРАЯ ГОСУДАРЫНЯ, и до счастливеЙшего состояния своих подданных попечение свое простирая, открыла училища ${ }^{3}$, в которых юношество во всяком благоразумии воспитывается, наукам и художествам обучается и по правилам здравого рассуждения до того приводится, чтобы из оного в Российской Империи могли быть во всяком звании полезные и искусные люди. Сколь ВСЕМИЛОСТИВЕЙШУЮ ИмеАМ МЫ ГОСУДАРЫНЮ, которая, не довольна будучи благополучием своего века, между столь многими пространнейшего государства делами о благоденствии

мира. - Т. ІІІ. Рим; Под ред. акад. В.В. Струве. М., 1953. - С. 21-33).

3 Вероятно, имеется в виду Воспитательное училище при Императорской Академии художеств, которое было открыто в 1764 г. В это училище принимались дети пяти-шести лет. После девятилетнего обучения учащиеся завершали образование в одном из высших классов - историческом, портретном, гравюрном, скульптурном, архитектурном. Необходимо учитывать, что работа автора была опубликована в 1766 г., когда Екатерина II еще не все осуществила в области развития образования и открытия училищ. Например, в 1772 г. было открыто Императорское Коммерческое училище; Комиссия по учреждению народных училищ, созданная Екатериной II в 1782 г., разработала к 1786 г. Устав народным училищам Российской империи, который предписывал «в каждом губернском городе быть по одному главному народному училищу». 
потомков и будущих веков неусыпно печется. Сколь ПРОЗОРЛИВЕЙШУЮ, которая за учреждение воспитания женского пола ${ }^{1}$ бессмертия достойна!

Остается пятый спосо6 умножения подданных, то есть иностранных принимание, между нами довольно ныне известное. Ибо АВГУСТЕЙШАЯ МОНАРХИНЯ и сего вспоможения к размножению подданных, в пользу Империи служащего, не оставила и чужестранцев, всемилостивейше призванных, принимает с несказанной щедротой. Но пространство сей материи велит мне оставить оную до другого времени и от предприятия дальнейшего о сей изъяснения меня отвлекает, дабы, почтеннейшие слушатели, вашего в слушании терпения не лишиться. В предложенных же мною к умножению подданных споспешествующих средствах видели вы велИкУю ВСЕМИЛОСТИВЕЙШЕЙ НашеЙ ГОСУДАРЫНИ неусыпность, попечение и премудрость.

Сии и другие неисчетные благодеяния, которыми мы АВГУСТЕЙШЕЙ нашей МОНАРХИНЕ обязаны, при сем торжественном и всерадостном, за

1 Первое учебное заведение для женщин в России - Императорское Воспитательное общество благородных девиц (Смольный институт) открылось по инициативе Екатерины 16 мая 1764 г. Также инициатором открытия института был общественный деятель И.И. Бецкой (17041795). Учреждение было открыто при Смольном монастыре. На основе Смольного института в России стали появляться другие учебные заведения для женщин. четыре года² перед сим благополучно совершившемся ЕЕ ИМПЕРАТОРСКОГО ВЕЛИЧЕСТВА На ВСерОсСИЙСКИЙ Императорский Престол восшествии, ныне усерднейше празднуемом, всех нас побуждают, чтобы мы о здравии, невредимом благосостоянии и долгоденстВИИ БЛАГОЧЕСТИВЕЙШЕЙ нашей ГОСУДАРЫНИ Всевышнему БОГУ искреннейшие принесли молитвы. Да Сохранит Господь ЕЕ ИМПЕРАТОРСКОЕ ВЕЛИЧЕСТВО, ВСЕПРЕСВЕТЛЕЙШУЮ, ДЕРЖАВНЕЙШУЮ, ВЕЛИКУЮ ГОСУДАРЫНЮ НаШУ ИМПЕРАТРИЦУ ЕКАТЕРИНУ АЛЕКСЕЕВНУ. Да собЛюДеТ Всевышнее непостижимое Существо в надежду Отечества возрастающего законного Всероссийского Наследника, Его Императорское Высочество, благоверного Государя Цесаревича и Великого Князя ПАВЛА ПЕТРОВИЧА. Да подаст всеблагий БОГ ВСЕМИЛОСТИВЕЙШЕЙ МАТЕРИ ОТечеСтВа всякое благополучие! Таким образом, Россия, в столь короткое время толикие великой благости, милости и премудрости доказательства, от АВГУСТЕЙШЕЙ СВОеЙ МОНАРХИНИ ПРОИСходящие, видя, с пиитой ${ }^{3}$ воскликнуть может: "По прошествии нескольких лет, воззрев на мои области, удивлюсь изобилию».

2 Правление Екатерины II длилось с 1762 по 1796 г. В середине 1766 г. кончился четвертый год правления.

3 Пиит (греч. поıпт́́, от поเє́ - делаю) устаревшая славяно-византийская форма слова «поэт». 